\title{
THE BREEDING ECOLOGY OF FOUR SPECIES OF HERONS AT LAKE ALICE, ALACHUA COUNTY, FLORIDA
}

\author{
By \\ DONALD ALISON JENNI
}

\begin{abstract}
A DISSERTATION PRESENTED TO THE GRADUATE COUNCIL OF
THE UNIVERSITY OF FLORIDA

IN PARTIAL FULFILLMENT OF THE REQUIREMENTS FOR THE DEGREE OF DOCTOR OF PHILOSOPHY
\end{abstract}

UNIVERSITY OF FLORIDA

June, 1961 
PREFACE AND ACKIOWLEDCITINTS

In 1957, Florida was emerging from a severe drousht. The long dry period, coupled with the continulng destruction of lonf-legged wading bird habitat which has accompanied the development of Florlda, seemed to be bringling the numbers of long-legged wading birds to dangerously low levels.

Officlals of the Florida Audubon Soclety were greatly concerned over this decline and as a result established a three year research grant to support a study of the basic ecology of herons. Their interest made this study possible and to this conservation organization I am deeply indebted. I. John H. Storer and Miss Lisa Von Borowsky, president and vicepresident of the Florida Audubon Society generously shared with me the benefits of their many years of heron observations in Florida. Tne National Wildlife Federation was also concerned and in 1959 awarded the study a research frant, and to them I am also indebted. The Florida Academy of Sciences awarded the study a rescarch grant in 1959.

Access to Lake Allce was arranged with the cooperation of the staff of the Arricultural Experiment Station. I appreclate the help of several fellow graduate students who assisted in identifying food items and accompanied me on trips.

Chairman of my supervisory comittee, Dr. J.C. Dickinson, Jr., was of assistunce throughout my work and I gratefully acknowledife his help. Other members of my conmittee gave willingly of their time and counsel and I especially appreciate their critical reading of tris dissertation.

Mary Jenni provided financial and moral support. 
PREFACE AMD.ACKROULDEMMENTS. . . . . . . .

LIST OF TABLES ........................ IV

LIST OF FIGURES ................ v v

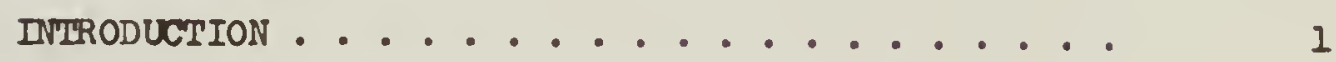

STUDY AREAS AND METHODS ..................... 3

REPRODUCTION ................................. 16

FEE DING ................................. 58

COMPARISON OF REPRODUCTIVE HABITS OF THE SEECIES . . 78

COMPARISON OF THE FEEDING HABTTS OF THE SPECIES • • 95

CONCLUSIONS ........................... 106

LILERATURE CIIED ................. 113

BIOGRAPHICAL SKETCH ................. 116 


\section{LIST OF TABLES}

Table

1. Frequency Distribution of Clutch S1ze of Snowy

Egret8, Lake Al1ce, 1960 . . . . . . . .

2. Frequency Distribution of Clutch S1ze of Cattle Egret8, Lake Allce, 1960 . . . . . . . .

3. Frequency D18tribution of Clutch S1ze of I1ttle Blue Herons, Lake Al1ce, 1960 ........

4. Frequency D1stribution of Clutch S1ze of Loufsiana Herons, Lake Alice, 1960 . . . . . . . .

5. Analys1s of Flfty Pellets Regurgltated by Young Snowy Egrets . . . . . . . . . . . .

6. Analysis of Flfty Pellets Regurgitated by Young Cattle Egrets.................

7. Analysis of Flfty Pellets Regurgitated by Young Little Blue Herons ..............

8. Analys1s of Flfty pellets Regurgltated by Young Loulslana Herons ..............

9. The Specles of Trees and Bushes Used By Four Specles of Herons for Nest Bullding at Lake Allce, 1960 . . . . . . . . . . .

10. Nesting Statistics of Four Species of Herons at Lake Allce .................

11. Mortal1ty of Eggs and Nestlings of Four Herons, Lake Al1ce, 1960 . . . . . . . . . . . 


\section{LIST OF FIGURES}

$\underline{\text { Page }}$

1. Temperature-rainfall relationships at Lake Alice, averages of data gathered 1954-1961 (Anonymous, 1961)

2. Map of penlnsular Florlda showlag location of heronries and other major polnts mentioned

in text .................. 
THE BREEDING ECOLOCY OF FOUR SPECIES OF HERONS AT LAKE ALICE, ALACHUA COUNYY, FLORIDA

\section{INTRODUCTION}

There is a large literature dealing with the herons and egrets. Most of this literature consists of: (1) examples of unusual feeding behavior in this highly adaptive group; (2) unusual geographic records of these birds, which wander extensively after the breeding season; (3) recards of soft part colors, which appear to vary w1th the season In at least some specles; (4) discussions of their all-whlte coloration; and (5) general observations on the locat1on, s1ze, and specles compos1t1on of local and, sometimes, newly established heronrles. In the last decade the literature has been swelled by reparts on the remarkable range expansion of the Cattle Egret (Bubulcus 1b18). But all th1s Ifterature does little to clarify the total blalogy of these b1rds. Although we may never know as much about them as we know about the birds that nest in more readily avallable places, there have been some recent studles that ald greatly in our understanding of these blrds.

Meyerrlecks (1960) published a detalled discussion of the breeding behavior of the Green Heron (Butarldes virescens) and made an interestIng Introduction to the comparative ethology of the Ardeldae by comparIng the Green Heron w1th four other specles. Valverde (1955) studied the large mlxed heronry at Camargue, France, and has published the best account of ardo1d ecology to date. There have been a few reports on the breeding behavior of varlous spec1es. Noble and Schmldt (1938), Allen 
and Mangels (1939), and Noble (1942) wrote about the Black-crowned N1ght Heron (Nyct1corax ayct1corax), and Verwey (1930) published on the Gray Heron (Ardea c1nerea). Weller (1961) discussed certaln aspects of the post-laylang breeding blology of the Least Bittern (Dxobrychus ex111s). There has been no systemat1c study of the ecology of a mixed breeding colony.

\section{Purpose of the Study}

The most comon harons of the Galnesville, Florlda area, are the Snowy Egret (Leucophoyx thula), I1ttle Blue Heron (Far1da cserulea), Louislana Heron (Bydranassa tricolor), and Cattle Egret. At the start of my study these appeared to have basically 1dentical ecology, except for the consplcuously different feeding hab1ts of the Cattle Egret. My purpose was to gather information on the virtually unknown bas 1c breeding blalogy of these four specles, to study their feeding behavlor, and finally to study the food hab1ts. The alm was not only to learn the facts, but also to learn samething about the birds' Interspec1f1c relationshlps, and thelr relationshlp to the ir environment, especlally to the most interesting but least known part of their enviroment, the heronry. I hoped that such a study would provlde Infarmation that could help explain what a heronry 18, what 1 provides the birds, and would perhaps eventually help solve the Intriguting problem of why even undisturbed ardelds wlll abandon one area long used as a beronry to breed in another as yet untried area. Though progress has been made, a full and deep understanding of the heronry is still distant. We need still to learn a great deal more about the lives of the Individual birds as well as the Individual specles, and especlally we need to learn the role of the heronry in their I1ves. 
STUDY AREAS AND METHODS

Most of the observations reported here were made near Gainesville, Alachua County, Forida, primarlly at Lake Allce and Payne's Pralrie, but observations were made in many other areas. The cllmate of the area is nearly semf-tropical and the long sumers are hot and wet with high relative humidity. The winters are shart, mild, and considerably drier than the sumers. The temperature usually goes below freezing several times during the winter months. Flgure 1 shows the temperature-rainfall relationshlps based on averages of dats obtained from 1954 through 1960 at the wather station adjacent to Lake Allce (Anonymous, 1961).

\section{The Gainesville Area}

Gainesville, just southeast of the center of Alachua County, Florida, 1s located in the Central Highlands near the northern end of the Farlda peninsule (Cooke, 1945) and is about mldway between the Atlantic ocean and the Gulf of Mexico (see Flgure 2). The area around Gainesville supports a large number of herons. The terrain is mostly gently rolling hills w1th 1nnumerable ponds and sinks and w1th several large wet prafrles and lakes south of Gainesville. Plne flatwoods extend nor theast of the city. The elevation varies from a maximum of about 200 feet to about 50 feet near which latter level lle the large wet pralries in the southern part of the county. The area is underlain by limestone and part of the uplands show karst topography. Practlcally all the solls are fine sand originally derived from Coastal Plain sediments (Taylar et aㅡ., 1954). 


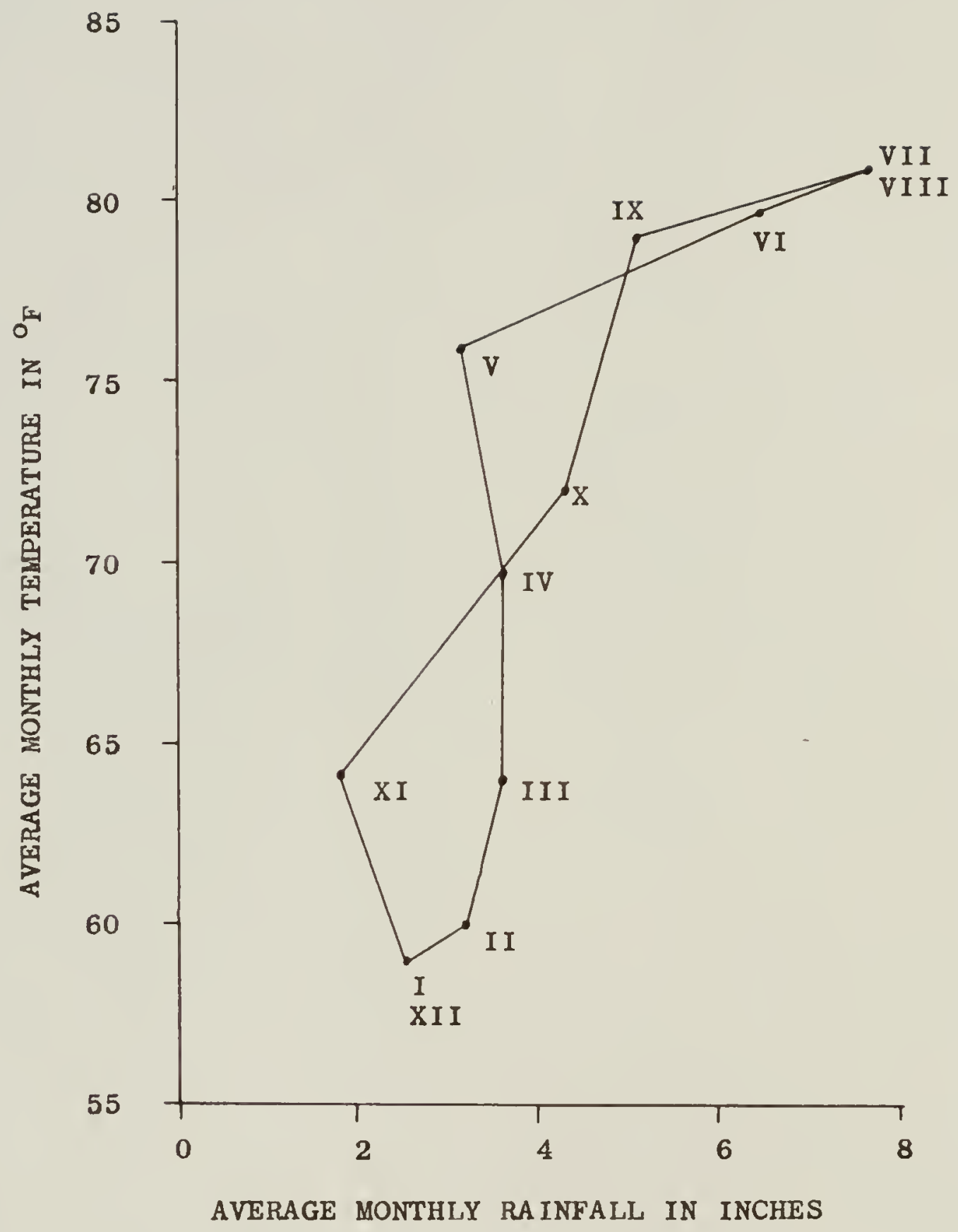

F1gure 1: Temperature-rainfall relationships at Lake Allce, averages of data gathered 1954-1961 (Anonymous, 1961). 


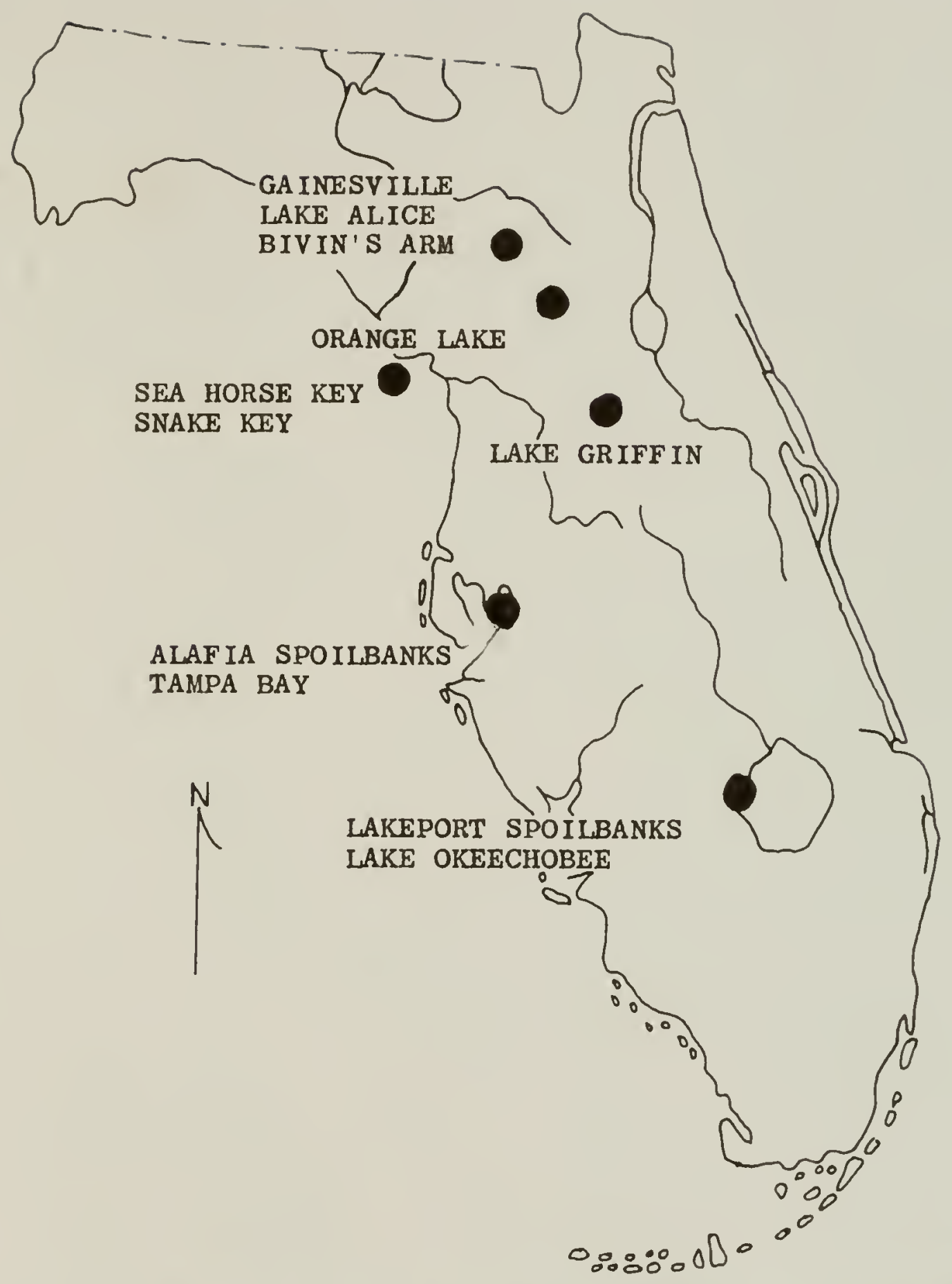

Figure 2: Map of peninoular Florlda showlag location of heronrles and other major points mentioned in text. 
There are three major types of vegetation: hardwood hamocks, pinelands, and wet lands. The more hydrlc hamocks around the prairles and lakes are character1zed by magnolla (Magnolla grand1flara), water-oak (Quercus nlera), laurel-oak (Quercus laurifolia), and cabbage palm (Sabal palmetto), and the more open upland hamocks by IIve-oak (Quercus VIrglniana), hickary (Carya aquatica), and sometimes longleaf (Plnus australus) or loblolly pine (Plnus taeda). There is practically no mesic hammock in the area today; most of $1 t$ has been cut over, and much of $1 t$ has been cleared for agricultural or other development. Northeast of Galnesville there are extensive plne flatwoods dominated by slash pine (P1nus palustr1s) and saw-parmetto (Serenoa repens) w1th numerous baldcypress (Taxodium distlchum) and loblolly-bay (Gordonla laslanthus) ponds. There are also flatwoods scattered throughout the area and a few undulatIng areas of longleaf pine (Laessle, 1942, and Taylor et al., 1954).

The extensive wetlands are responsible far the large heron population In the Galnesville area; and the most 1mpartant of these wetlands is Payne's Pralrie or Alachus Lake, whlch in recent years has been the principal feeding area for herons around Galnesville. Thls nearly level pratrie varles from permanently flooded to, especlally around the edges, dry land. Much of It 1 s covered whth between one Inch and two feet of water, but during the wet summer season the water rises and covers practically all the prairle. The vegetation of the deeper parts of the pratrle include water-hyacinth (E1chhornia crassipes), plckerel weed (Pontederla lanceolata), arrowhead (Saglttarla spp.), and otbers, wh1le the shallower and seldom flooded parts of the prairle support dog-fennel (Eupatorium spp.), maldencane (Pan1cum hemitamum), and a w1de varlety of other grasses. 
There are other wet proirles in the area. Levy Lake, Lodith Lake, Tuscawilla Lake, Kanapaha Pratrie, and Hogtown Prairle are the larger and more 1mportant of these areas. They are all simflar to Payne's Prairle and they are covered with simflar vegetation. The differences between them are primarliy due to different water depths. In addition to these prairies there are extensive marshes and wetlands surrounding crange Lake, slightly farther south; and there are innumerable small proirles, pands, sinks, and marshy shore lines with regetation similar to the Payne's Prairle throughout the ragion. Practically all of these areas are used by the herons for feeding at loast occasionally.

\section{Heronrles near Gainesville}

Social herons have nested in at least three separate colonies in the Galnesville area. A floating 1sland, BIrd Island, in Orange Lake has supported a heronry for many years (Baymard, 1912). A moderate sized group of berons bred in emergent trees and bushes in BIvin's Arm just south of dainesville for many years (DIckinson, 1946). Since 1948 there has been a large mixed heromry at Lake Alfce on the University of Florlda carpus. In 1948 the herons falled to breed at B1vin's Arm and have apparently never made any effort to re-establish themselves there. These appear to be the birds that occupled Lake Allce. The regetation of these three areas 1s quite simflar. The trees and bushes for the most part are the same specles. Besldes their vegetation these three heronrles have other things in common. They are surrounded by water at least several feet deep, there are alligator populations, and there is practically no predation, and human disturbance is minimal. It is apparently these factors plus the presence of suftable nest sites and 
nesting materlal that were of prime importance in the original establishment of these heronr1es. The less soclal Green Heron and Least B1ttern nest at several other localities around Galnesville in addition to these three heronrles.

\section{Description of Lake Allce}

Because most of the observations presented later in this repart are based on data gathered at Lake Allce, I shall describe this heronry in mare detall. Lake Allce was arlginally a small pond of about 10 acres, but 1t fluctuated considerably (DIckinson, 1940). As the University of Flarlda campus grew, surface runoff increased. In 1948 an earthen dam was butlt just wost of the "lake." The hollow where lay Jonah's Sink, as It was formerly called, was flooded and the water spread out over an area of about 90 acres. Included in this newly flooded area were a low lylng buttonbush (Cepalanthus occ1dental1s) marsh and the margins of an extensive banmock of IIve oak, loblolly pine, and sweet-Bum (LIguidamber styraciflua), all of whlch were kllled by the water. Buttonbush replaced the hammock trees and wax myrtle (Myr1ca cerlfera), w1llow (Sal1x spp.), red maple (Acer rubrum), and elder (Sambucus simpson11) 1nvaded areas of shallow water. Water pennywart (Hydrocotyle spp.) grew over the top of the water throughout the swamp area, water-hyacinth grow over deeper but st1ll sheltered water. Plckerel weed, broad-leafed cattall (Typha latifolla), smartweed (Polygonum spp.), and many other emergents Invaded the perlodically flooded lake margins. What attracted the herons to Lake Allce, at least what they used when they flrst arrived at the lake, were the bushes and trees in whlch they nested. The specles of bush or tree did not appear to be of any impartance; It appears that the only thing the trees or bushes must provide the herons is a physically 
sultable nest site. To be acceptable to herons for nest sites, the trees must be located in a place difflcult of access to predators. Thus Forlda herowries are usually on 18 lands or over deep water.

Besldes nesting in red maple, buttonbush, elder, wax myrtle, and wlllow in Lake Allce, they nest elsewbere in Flarlda, in such diverse vegetation as mangroves, cabbage palms, black gum, bald-cypress, maldencane, and others. Thus 1 must be reasons other than the kinds of nest trees avallable that caused the herons to nest at lake Allce for the first time. It appears most 11kely that what the lake offers is an abundance of sultable nest sltes sufflclently high above the lake surface, over or surrounded by deep water, and wth sufflclent twigs for nests. What caused the birds to abandon the other breeding area, BIvin's Arm, 18 not clear (Mounts, 1949).

During the years 1958, 1959, and 1960 the woody growth of Lake Allce continued to die back; the only remants of the ald hamock belng a few huge oak stumps. Most of the buttonbush that was rooted in more than a couple of feet of water was in poor condition and put out only a few new twlgs each yoar. By far the best woody growth in the lake during those years was on the west bar, a shallow bar in the west end of the lake, in other shallow areas near the middle of the south share, and on the floatIng 1slands. There are several floating 18lands in the southeast bay of Lake Allce. It is on these 1slands and on the west bar that nearly all of the birds have nested during these three years.

It was on the largest of these floating 18lands that most of the quantitative date on the breeding ecologs of the herons was collected in 1960. The 1sland was anchored by the tree roots and was surrounded by water $81 x$ or more feet deep. The 1sland raft was composed of I1ving and dead roots, which acted as the principal blnding agent, and decaved and 
decaylng organic matter, which made up the bulk of the subtrate. The Iiving plants, especially their roots and tubers, plaved a most important role in maintaining the integrity of this island. Water penaywort grew over most of the area and was the only ground cover in the heavily wooded portions. A begonta (Begonia semperflorens) grew where there was partial shade, and broadleafed cattall and water w1llow (Decondon verticillatus) grew in exposed places. The water pennywort grows out over the water for several feet around the edge where it is invaded by water-hyaclath. Lush growths of water-hyac1nth marks the positions of ponds and channels which transected the study area. Red maple is the dominant tree and occurs throughout the middle of the island. Buttonbush is as numerous but does not attain the size of the red maple and occurs over the entire area, least abundantly around the edges. Wax myrtle is not abumdant and is scattered through the middle. Willow grows mostly around the edge of the laland where 1ts large, Irregular trunks grow out over the water. Elder grows only in maximum sunlight and occurs around the edges.

\section{Arde1dae of Lake Allce}

The ardelds that are known to have nested at Lake Alice include: Green Heron, I1ttle Blue Heron, Cattle Egret, Conmon Egret (Casmerodius albus), Snowy Beret, Loulsians Heron, Black-crowned N1ght Heron, and the Least Blttern. In addition Glossy Ibis (Plegadis falcinellus) and White Iols (Eudocimus albus) have nested there. The Anhinga (Anhinga anhinga) also pests in essociation with the heronry. The Cattle Egret first nested at Lake Allce in 1954 (Rice, 1956), and has nested there each year since. Common Egrets have not nested there since at least 
1958, and in 1960 for the first time the White Iols did not remaln at Lake Allce to breed although they did appear early in the spring. Other long-legged wading blrds found at Lake Allce, but whlch are never known to have nested there Include Great Blue Heron (Ardes herodias), Yellowcrowned Night Eeron (Nyctanassa V1olacea), and Wood Ib1s (Mycter1a amer1cana).

Durling the 1960 breeding season, when the quantitative data on reproduction and food habits were gathered, the populations of the ardelds at Lake Allce were conservatively estimated as: Green Heron, 8 palrs, Llttle Blue Heron, 225 palrs; Cattle Egret, 300 palrs; Snowy Egret, 275 pairs; Loulslana Heron, 150 patrs; Black-crowned N1ght Herons, 2 peirs; and Least Bltterns, 12 patrs. Thus there were nearly 2,000 adult ardelds in the heronry during the nesting season. About 200 Glossy Ib1s and 2,000 White Ib1s roosted at the lake for a few days early In the 1960 season, but only 2 palrs of Glossy Ib1s butlt nests.

A few herons are found in the Galnesville area during the winter. Although there was a winter roost at the east end of Payne's Prairie, these blrds roosted primarlly at Lake Allce. During the three years, the population began to bulld up after mid-February, and the adult population reached 1ts peak during Apr1l when most nesting was 1nitlated. A few birds fed at Lake Allce untII nesting started, but after that the adults no longer fed there. Later, the young fed around the edges of the lake, especlally near the heronry, but they continued to be fed by the adults during this per1od. In the main most of the herons fed on Payne's Prairle from the time they plrst arrived. One or two birds usually fed at nearby sewage settling ponds. In addition, sinks, small woods marshes, streams, roadslde ditches, and other waters are occasionally 
visited by foraging herons. When there was a sudden concentration of food at one of these latter places, large numbers of herons congregated there.

As the young started flylng and were able to move away from the lake to feed, there was a movement of herons away from the Gainesville area. The Increase in the local heron population which must be expected as a result of that season's production, was never mare than tempararily attained. Their numbers dwindled durlang late september and October, and during late November or early December the1r numbers fluctuated sparadically, probably as the result of southward mlgration. By midDecember the1r numbers were greatly reduced and remalned lower through the wlnter than at any other season.

\section{Other Heronrles}

Although most observations were made at Lake Allce, Payne's Pralrie, and elsewhere in the Galnesville area, I studied herons at several other places In Florida durlng 1958, 1959, and 1960. The more Important of these localties are shown in Flgure 2. I made repeated observations on the feeding bchavlor of herons breeding at Orange Lake, Marlon County; at Lake Griffin, Lake County; and at Snake and Sea Horse Kpys, Lery County. In addition I made three visits Into the heronry at Lake Griffin In 1960 and one visit each Into the heronrles at Lake Butler, Orange County; Lake akeechobee, Clades County; Tampa Bay, H1llsborough County; and Snake Key, Levy County. Many additional casusl observations not Included in this repart were made at these and otber Flarida localities outs1de the breeding season. 


\section{Me thods}

The method employed most was observation, often with binoculars or telescope. Observations of adult behavlor throughout the breeding season were made from several vantage polnts around Lake Allce during 1958, 1959, and 1960. In 1960 detalled observations were made Inside the heronry. As each nest was found it was tassed with a number. The tagsed nests were v1sited dally and the condition of the nest, number of eggs, or number of young was recorded. A plece of chrome plated tin was attached at an angle to the end of a ten-foot pole and was used to see Into overhead nests. The eggs in nests that were low enough to reach were marked wth waterproof 1 nk as they were lald and the fate of each Individual egg was fallowed. Two blinds were placed on the 1sland and were used occastonally.

During the 1960 season a total of at least 495 nests were tragged. There was no way of ldentIfylng the owners of these nests at first, but since they were kept under dally observation most of them were eventually 1dent1fled. However, many of these nests were not completed by the adults, many others were destroyed before the 1dent1ty of the adults could be determined, and ownersh1p of many nests was not determined unt1l the young hatched. At the end of the season, dally observation had been made on a total of 275 successful, marked, and 1dent1fied nests. Th1s number Included 102 Snowy Egret nests, 85 Cattle Egret nests, 58 I1ttle Blue Heron nests, and 35 Loulslana Heron nests. Observations on practically all of these nests extended from early nest bullding through rearlag of the young.

Observations of feeding adults were made primarlly on Payme's Pralrie where most of the blrds that nested at Lake Al1ce fed, and although $1 t$ 
was relatively unimportant as a feeding area, at Lake Allce. Study of the herons' food hablts was based on the analysis of materlal obtalned from nestlings and older, but stlll flightless, herons. These young birds regurgltated the ir last meal when they were disturbed. The amount of disturbance necessary to make them regurgitate varled not only between specles, but also between broods. Pellets of 1dent1flable food were preserved lmmedlately in 10 per cent formalin. From one to several days later the pellets were washed and transferred to 30 per cent 1sopropanol. Later the food 1tems were 1dentifled, counted, and their valume determined by absarbing excess water with paper towels and then measuring the volume of water the food displaced. Because of possible distartion, valume is discussed as per cent of total valume. Although many more pellets were collected, the discussion of food In this repart is based on the analysis of 50 relatively undigested pellets recovered from young of each of the four herons.

Mmerical data are usually presented as mean data. These flgures are followed by parenthetical statements of the size of the samples, the range of the observations, and their standard devlations (abbreviated as S.D.). Where it would be redundant, this parenthetical infarmation 1s not glven. The standard devlation is Included as a measure of the dispersion of the observations about the mean. The inclusion of these data serve as an Indication of the biological significance of the means, and give the reader additional Information, and 1t was urged by Davis (1955) for one, that when avallable this 1nfarmation always be Included. The " $t$ " test is used to compare two means. In these tests, the bypothesis is made that the two means are equal. The level of sigatflcance 
1s .05 . When the hypothesis is rejected, it is assumed that the two means are Prom different "populatlons." Statements regarding the signiflcance of the means are accompanled by the " $t$ " values. 


\section{REPRODUCTION}

One specles or several specles may nest in a given heronry. When more than one specles nests, as at Lake Allce, It is called a mixed heronry. The term rookery, though often applled to heronrles, is the name of a place where Roaks (Corvus frugtlegus) nest and is not properly applicable to herons. In this chapter the breeding activity of the four most numerous herons at Lake Allce 1s described. Following the three Introductory sectlons whlch deal whth all four specles of berons, are individual accounts in whlch the statistics of each specles are presented.

\section{Winter Status and Spring Arr1val}

Herons winter in large numbers in south Flar1da, but are not1ceably less abundant along the northern Florlda coasts and along the Central Highlands. Although the Galnesville area is marglnal as a wlatering area for ardelds it is not far distant from acceptable wlntering habitat. The abundance of ardelds in the Galnesville reglon during the winter fluctuates drastlcally and appears to be related to the weather espec1ally temperature. Durlng December and early January there are fewer birds in the area than at otber times. After a few days of lowered temperature, ar two ar three alghts of freezing temperature, pract1cally no Snowy Egrets, L1ttle Blue Herons, or Loulslana Herons can be found. After about a week or ten days of average temperature, or after several days of above average temperature, and later, wth the approach of 
spring, the ir numbers gradually 1ncrease and mixed flocks of 100 to 300 ar more roost at the lake. Present observations indicate that the Cattle Egret is not going to follow this general pattern, but rather will use Lake Allice as a regular winter roost. Through the winter of 1959-1960 approximately 100 Cattle Egrets, and in 1960-1961 approx1mately 250 cattle Egrets roosted at Lake Allce. These wintering birds fed in different places than did Cattle Egrets during the breeding season; they followed different local fllght paths, and roosted in a part of the lake not used far breeding by any specles of heron during the 1958, 1959, or 1960 seasons.

During February, or even as early as late January, the number of berons roosting at Lake Allce begins to 1ncrease. There is a gradual build-up until a maximm 1s reached about the time nesting begins. Throughout this perlod the birds Ply directly to the roost where the Individuals remain qutet and seldom move about except for an occasional conflict over a perch. Occasionally a whole group of birds will take flight and move to a dffferent part of the lake to roost, but in the evening later in the season, the Individuals are very active when they arrive at the roost.

\section{Onset of Breeding}

The first activity which seemed to be related to the onset of breeding was the increased restlessness of roosting birds. In mid-March Individuals started flyling around within the roosting area. There did not appear to be any directiveness to thls new behavior. The birds did not seem to be engaged in any productive effort and the1r behavior apparently only reflected a general restlessness. Another change at this 
time was the return of a few birds to the heronry as early as two hours before sunset, and, In the marning, a few stayed long past the departure of most of the other birds. These Individuals perched in the bushes and trees part of the time but spent most of their time "exploring" the heronry, hopping from $11 \mathrm{mb}$ to $11 \mathrm{mb}$ and making shart fllehts from one part of the heronry to another. After only one ar two days the males centered their activitles around a partlcular bush or tree and the Ir shart fl1ghts brought them back to this place. They directed threat displays at every heron that approached them closely, regardless of spec1es. Here they eventually performed the courtship displays. The males did not feed in these areas and had to leave them unoccupled when they left to feed. After pair farmation one of the pair always remalned in the now established territary.

When they flrst became mare sedentary, the males spent most of their time defending that place by directing threat postures at and attacking other individuals. Although this primarlly hostile behaviar has sexual Implications, the males' behaviar changed and became primarily sexual after one to several days of hostlle behavlar. It is not clear whether this shift in behavior was due to other birds avolding the area defended by males or to continued development of the males' sexuality, but it was probably brought about by both. The most impressive and most complex sexual display is the Stretch Display, described in detall by Meyerrlecks (1960). The male has established his territary when he begins performing the Stretch D1splays, but may leave during mid-day and In so dolng he runs the risk of losing that territory. The stretch Display is apparently camon to all herons, but there were interesting differences. In the way the display was performed by each of the four 
specles studied. This was the primary sexual display that attracted females. A male of any of these specles which perfarmed a serles of Stretch D1splays with v1far and with bold movements was soon surrounded by a group of hls kind (although sexes of the individuals in the group were unknown to the observer later behaviar indicated that the group usually included at least one female.) When an Individual approached too close, the male 1nterrupted the displays long enough to drive that Individual away and then returned to his perch and resumed the stretch Displays. A female ready for palr formation would repeatedly approach the male and then retreat from him as he came at her in a threatening att1tude. The male would eventually not threaten the female and the palr bond was established. W1thin a few days of pair farmation the blrds started distingulshing between Indivlduals IIylng through the territory and those actually invading the terr1tory, and they 1gnored the transients.

The breeding behavior of herons has been Invest1gated by others and a detalled discussion of their comparative breeding behavlar is beyond the scope of this study. Published reparts on heron breeding behavlor Include Meyerrlecks' compar1son of several specles (1960), detalled descr1ptions of Black-crowned N1ght Heron behavlor by Noble and Schmldt (1938) and by Allen and Mangel (1940), and an exhaust1ve repart on the Gray Heron by Verwey (1930).

\section{Sequence of Nesting}

Although most of the birds arrive four to elght weeks before the start of breeding, and there appears to be no substantial difference in the time the four specles arrive at Lake Allce, the specles do start nesting at slightly different times. Practically all Loulsiana Feron 
nesting is confined to the early part of the season. In 1960, 94 per cent of all clutches were completed before April 28, most of them during the first two weeks of April. Most L1ttle Blue Heron nesting was also confined to the early part of the season. Sixty-seven per cent of the Little Blue Beron clutches were completed by April 28 but about 30 per cent of the IIttle Blue Heron clutches were not completed until between mid-May and early July, mostly during the last three weeks of June. Snowy Egrets also started nesting early in the season, but unlike the Loulslana and L1ttle Blue Berons wh1ch had completed most of their clutches during the flrst two weeks of April, the Snowy Egrets completed most of the ir clutches during the last two weeks of April. Elghty-seven per cent of all of the1r clutches were completed by April 28, and although a few new nests were buflt throughout the season, the rate of new nest construction decreased rapldily after the f1rst peak. Cattle Egret nesting started about the time the Snowy Egrets reached the1r peak, that is about two to three weeks after the other specles started nesting, and the Cattle Egrets reached their peak two weeks later than d1d the Snowy Egrets; 64 per cent of all Cattle Egret clutches beling completed by May 12. Additlonal Cattle Egret clutches were completed throughout the season and there was a second peak of activity during the flrst half of July. Cattle Egret nesting effort was mare equally distributed throughout the season than were nesting efforts of the other specles. The last Cattle Egret clutch in the study area was completed July 15 . Some were completed even later elsewhere in the heronry. 


\section{Snowy Egret}

\section{Nest S1te}

Snowy Egrets bullt their nests on the sturdiest sites avallable 10 the territaries which had been established by the males. The PIrst territorles established in each new area of the heronry as it expanded during the season were those few areas that included remnants of old nests. Old nests offered especlally sturdy places to preen, court, copulate, and evontually nest, and were consequently in great demand by all specles of herons. If avallable in the territary a nest left over from the prevlous year was used as the base for a new nest. Next in impartance as nest sites were $11 \mathrm{mbs}$. The main trunk of the tree was used as a suppart far one side of the nest, and the structure was bulit out on two 1 imbs.

The third most comon nest site was in the basket-like growth that had formed at the stubby end of some trunk as a result of herons breakIng off nesting material in previous years. Same species broke twlgs off IIving trees, and when the terminal shoot, especially of wax myrtle, Is thus pruned, growth of $11 \mathrm{mbs}$ immediately below that point is stimulated. The result is the basket-like structure whlch makes a very sturdy nest s1te. Less explo1ted nest sites included horlzontal IImbs such as those commonly used by Little Blue Herons.

The average helght at whlch 96 snowy Egret nests were bullt in 1960 was 5.7 feet above the heronry floor or the lake surface (range 3-11 foet, S.D. - 1.33). Snowy Egrets butlt mare of the Ir nests in red maple (43 per cent of all nests in 1960) than in any other tree or bush. Buttonbush was second (26 per cent) in Impartance and elder, w11low, and wax mythe were used for 18,7 , and 6 per cent of the nests respect1vely. 
The nesting substrate of Snowy Egrets in Flar1da 18 described as cypress and mangrove swamps and buttonbush ponds (Howell, 1932) and wlllow 1slands (Bent, 1926). Elsewhere they bulld their nests in red cedar (W118on in Bent, 1926), prickly pear and hulsache and reeds (Bent, 1926). The nests are placed on the lower $11 \mathrm{mbs}$ from 8 to 12 feet above the water (Howell, 1932), in wlllows of 8 to 15 feet (Bent, 1926); but nests on V1ngt-une Island, Texas, were bullt very close to the groumd or at helghts up to 5 ar 6 feet. In coastal mangrove heronries, such as Snake Key ar the Alafla Rlver spollbanks on the west coast of Florida, the nests were much higher than at Lake Alice and higher than those mentioned in the above reparts; the lowest nosts were about 8 to 12 feet above the ground.

\section{Nest Bullding}

Nesting material was gathered only by the male and brought to the female who worked it Into the nest. When the twig-carrylng male was a few feet from the female he elevated his crest, drew his neck into an " 8 " curve and elevated his algrettes. The female responded with a simtlar feather movement, reached out and took the twig in her b11l. Both birds immediately sleeked their plumage as the female turned directly to the nest with the twig. As nest bullding progressed the intensity of this display diminished untll the birds no longer elevated the algrettes, but they usually continued to elevate the crest. The female normally held the stlck near the mldale. Several effarts were usually needed to push it into the nest, pushing, sometimes getting it part way lodged and pulling it out again, untll it was well anchared. The twlg was dropped frequently, but the male usually found it on one of his later trips. 
All the stlcks were gathered from the ground or shallow water beneath the heronry. Howell (1932) commented that Snowy Egret nests are buflt of dead twigs. The usual pattern followed early in the season before vegetation became rank was for the male to return directly to the ground from the nest and walk around unt1l an acceptable twig was located. Often several were picked up and rejected and on occasion attempts to plak up tree roots or branches of large limbs were observed. The male walked back to the nest tree and climbed up to the nest if there were sultable footholds, otherwlse a big hop and a shart fllght of two or three wingbeats brought him close enough to the nest so that he could pass the twig to the female. Increased grouth of vegetation altered this pattern later in the season, and the male had to $\mathrm{fly}$ a short distance.

All the twigs in some nests were coated with mud. As the season progressed, females of all specles accidentally dropped sticks whlch they were working into thelr nests, and some nests were torn apart by the wind or other herons and scattered on the ground beneath the beronry. Fresh twlgs, some st1ll with green leaves, became as abundant on the beronry floor as were the ald mud-coated ones, and later in the season they were mare avallable than the other twlgs. These new twigs were used accarding to their avallabllity and snowy Egret nests bullt later In the season were easily distingutshed from older nests.

The pair spent from three to $81 x$ days, rarely as many as elght days, building the nest before the female started laylng; the average for 21 nests was 4.4 days (range $3-8$, S.D. $=1.15$ ). Nest bullding continued through egg-laying, especlally the first two or three days, but the nest was usually completed by the t1me the last egg was latd. 
The eradual but continual loss of twigs during incubation was offset by the addition of new material.

\section{Egg Layling and Clutch S1ze}

Snowy Egrets lald their eggs befare 9:00 in the marning. The first egg was lald from three to elght days after the adults started buflding the nest but the nest was seldom completed by then. The first egg often passed down Into or through the nest; and occaslonally the second egg was lost this way. The second egg was lald an average of 1.8 days after the first egg, and the other 1ntervals were 2.0 days between the second and third eggs, 1.9 days between the third and fourth, and 1.8 days between the fourth and f1fth eggs. The over-all average was 1.9 days between eggs (114 intervals, range 1-2 days, S.D. = 0.34 ). Th1s data is in areement w1th Dawson (1915) who on the basis of hatching pattern, concluded that the eggs are la1d on alternate days. At Lake Allce the most frequent two-day interval was between the second and third eggs. Intervals of mare than two days were not recorded. Typ1cally there was only one, one-day interval per nest, and the fifth egg was the egg most frequently la1d one day after 1ts predecessor. The adults spent an average of 7.3 days in egg laylng (average number of eggs laid times the average interval).

Snowy Egret clutches at Lake Allce (see Table 1) contalned an average of 3.9 eggs (102 clutches, range $2-5$, S.D. $=0.67$ ). Howell (1932) reports the clutch as three or four, but Bent (1926) says the clutch is ardinarily four or flve, sometimes only three and rarely six. Early clutches, that 1s those completed between April 4 and April 28, averaged 4.1 eggs ( 89 clutches, range $3-5, S . D_{0}=0.48$ ), but late nests contained substantially fewer eggs. Clutches completed between April 
Table 1.--Frequency Distribution of Clutch S1ze of Snowy Egrets, Lake Allce, 1960

\begin{tabular}{llccc}
\hline & \multicolumn{5}{c}{ Clutch s1ze } \\
\cline { 2 - 5 } & 2 & 3 & 4 & 5 \\
\hline All nests & 3 & 15 & 69 & 15 \\
\hline Apr11 4 to Apr11 28 & 0 & 7 & 67 & 15 \\
\hline
\end{tabular}


29 and June 16 averaged 2.9 eggs (13 clutches, range 2-4, S.D. - 0.62). These late nests are probably all renesting attempts of birds whose earlier attempts falled. The dfference between the means of the early and late clutches 18 signiflcant at the .01 level ("t" $=7.79)$.

The average number of eggs lald in nests that eventually contalned complete clutches was 4.1 (100 nests, range $2-8$, S.D. $=0.64$ ), but some eggs were lost befare the clutch was completed and additional eggs were certalnly lost before they were recorded.

There is no evidence that any of the Snowy Egrets ralsed two broods at Lake Alice. The nesting season is sufficlently long for ralsing two broods, but nest1ng activity decreased rap1diy and continuously after the inftial peak, and there was no evidence of a late second peak of activity. At least one brood of two young was ralsed fram the age of a few days by only a single parent at lake Allce durlng 1960, and it might be reasoned that one parent could be relleved from care of the first brood and start a second. However, even nest bullding behaviar demands two birds: a male to hunt twlgs and dellver them to the nest site and a female to take the trigs and fashlon a nest from them. Protecting a nest against depredations of other nest bullding herons and protecting the eggs from predators also require the presence of two individuals.

\section{Incubation}

Snowy Egrets usually started 1ncubating the day after the second egg was lald, or sometimes they started the day the third egg was lald. Although there was considerable varlation, the adults seldom incubated one egg, sometimes Incubated two eggs, but always started Incubating 
by the time the clutch contalned three eggs. The pattern of hatching of the young indicates that effective incubation may actually have begun somewhat earlier than observations of adult behavlor indicated. These observations conflict with Dawson's (1915) statement that, on the basis of hatching pattern in three nests, incubation starts with the laylng of the first egg.

The 1ncubation per1od averaged 22.4 days (39 nests, range 21-24 days, S.D. $=0.75)$. The most frequent incubation periods were 23 and 24 days w1th 21 and 12 observations respectively. Three nests hatched in 22 days. The incubation perlod of 18 days reparted by McInlhenney (1912) is the only one quoted by Bent (1926), and 1s the f1gure given by Sprunt and Chamberlain (1949). Elghteen days 1s appraximately the duration from the laying of the last egg to the hatching of the first young at Lake Alice. At Lake Alice both sexes incubate, and Bent (1926) has reparted this for other locallties. Although the Snowy Egret nest 1s an open netwark of twigs offering little protection from below agalnst cold ar wind, there appears to be no correlation between clutch s1ze or weather and length of Incubation period. The nest is important to the adults for several activities, but all it offers the eggs is protection from falling to the ground.

\section{Hatching and the Young}

The chlcks could usually be heard calling inside the egg for two ar more days before they plpped. The young may hatch completely in less than 24 hours, but most young plpped at least one day before they hatched. The young are covered with a moderate amount of white down whlch dries in a shart time. 
On the flrst day of hatchlng, the nests contalned one or two, rarely three chlcks, and they averaged 1.5 (80 nests, range 1-3, S. D. $=0.62$ ). The second day of hatchlng most nests contalned two or three chlcks, a few contalned one, and about half as many contained four as contalned one. They averaged 2.4 chlcks the second day (68 nests, range $1-4,8 . D .=0.76)$, an average of nearly one per neat hatohed between the flrst and second day. About half the nests had three on the third day and most of the others had two or four. They averaged 2.9 chloks on the third day ( 59 nests, range I-4, S.D. = 0.85). However Dawson (1915) found three nests in Callfornla in whloh the young hatched on alternate days, a sequence not observed at Lake Allce.

An average of 3.3 young hatched per nest (91 nests, range 1-5, S.D. $=0.96)$. It toak an average of 3.2 days (75 nests, range 1-6, S.D. $=1.14$ ) for all to hatch. The hatchlings were able to lift the 1r beads for only a moment at a time during the f1rst two days. On the third day they could keep the head elevated for considerable time and were often heard peepling. After a few days they became sllent when disturbed.

The parents brooded the young for several days, one parent nearly always on the nest. Bent (1926) reported that both adults care for the young, but one of them always remains at the nest. At Lake Allce especially during m1d-day and in June and July broods, the adults spent much of their time standing over the young shading them. McInhany (1912) provides an excellent photograph of an adult shading young. Both parents feed the young, but unt1l the young were ald enough to hold their heads up and strike at fore1gn objects that came to the nest, one of the parents always stayed at the nest whlle the other humted and 
brought food to the chlcks. After the young were about one week to 10 days ald, the parents no longer stayed on the nest through the day. After thls time both parents started hunting and bringing food to the young at the same t1me.

At first the young plcked food off the floor of the nest where It had been regurgitated by the adults. After a few days, they quickly passed through a stage of taking the food from the parents' b1lls, the several young grabbing for the b1ll at one time. The young next progressed to the procedure of stlaking their heads into the b11l and mouth, reaching down into the throst and Intercepting the regurgitated food on 1ts way up. In broods that hatched over a perlod of several days the oldest young might thus be taking 11 sh out of Its parents' throst while 1 ts youngest slbling was st1ll too weak to hold 1 ts head up.

\section{Martality of Eggs and Young}

The loss of eggs from nests between the time of laylng and the start of hatching was at least 5.4 per cent. Drring the hatching process there was a mortallty of 14.7 per cent. From egg laylng through hatchIng there was an over-all minimum martallty of 19.3 per cent.

The average number of hatchlings surviving unt1l two days after the last young hatched was 3.0 ( 86 broods, range 1-5, S.D. = 0.97 ), th1s is signiflcantly fewer than hatched (" $t "=1.67)$. The brood size was reduced st1ll further to an average of 2.7 chlcks by seven days after batching ( 77 broods, range 1-5, S.D. $=0.86$ ), and two weeks after the last young hatched, an average of only 2.2 young survived per nest ( 65 broods, range 1-4, S.D. $=0.84$ ). These losses are greater than those of the flrst two days. After two weeks the first hatchlings were often able to leave the nest and later est1mates of mortality are 
unrellable. The reduced number of observations of older broods is due in part to intentional termination of observations at same nests. The total mortallty durelng the first two weeks of nest $11 f e$ was 32.6 per cent. The over-all $108 s$ exceeded an average of one chtck per nest; of the 3.3 that hatched, an average of 2.2 chlcks per nest survived far two weeks. Practically all this loss was due to starration. The last chlck to hatch was conslderably behlnd the earlier ones in development and slze and was incapable of successfully competing with four siblings and often Incapable of competing with three. As each day passed the older nest mates developed and grew while the youngeat waned until eventually it died of starvation.

Nests that contalned four chlcks two days after hatchlng had an average of only 2.5 chlcks two weeks after hatchlng. Broods that contained three chlcks two days after hatching were reduced to an average of 2.3 by the end of thetr second week, and broods of two were similarly but much less drastically reduced to 1.8 checks. Thus 1.5 young were lost from broods of four, 0.7 were lost from broods of three, and less than 0.3 were lost from broods of two. It appears that the adults were able to feed and ralse a maximum of about 2.5 young per nest. Of the 3 I nests in whlch four ar mare young hatched, only two nests held as many as four two weeks later. The young that atarved were usually trampled into the nest by the ir s1blings, but were occasionally ejected from the nest. The minimum over-all loss of both, eggs and young from egs layling through the first two weeks of nest I1fe was 45.6 per cent.

There was a sharp increase in martality when the young first left the nest and started climbing around in the bushes and trees. At Iake 
Allce the trees and bushes were short and scrubby, and those young who fell to the ground were usually, but not always, able to get back to their nests. The young were extremely agile and used their heads and necks as prehensile alds in climbing. Nevertheless, during 1960 I found two large juventles hanglang dead. One was upside down whth the foot caught and the other was caught by the wing. Young that wandered Into the nest site of nearby birds were attacked, especially if the nelghbor was a Cattle Egret, and were driven or knocked from the tree.

\section{Cattle Egret}

Nest S1te

old nests were seldom avallable in Cattle Egret territories because other specles had already established territorles to include the old nests before the Cattle Egrets started nesting. But Cattle Egrets occasionally bullt on top of a nest formed earlier in the season by some other heron and later abandoned by 1t. Some of the Cattle Egrets which started nesting as late as June or July were able to use nests recently abandoned by young Snowy Egrets or IIttle Blue Herons. Cattle Egrets were the last to breed and generally acquired territorles and nest sites higher in trees and bushes than did the other specles. As a result there was less stable support for thelr nests. Heron territorles at Lake Allce had definlte vertical as well as lateral limits. The most favored nest site appeared to be in the basket-like growth of limbs whlch resulted from the breaking off of terminal twlgs for nest material in previous years. Cattle Egret nests were often built against the tree trunk on a pair of small $11 \mathrm{mb}$, in 
the fork of a horlzontal I1mb, which gave support in three directlons from the nest center; or between the two branches just beyond the fork. These nests were quite stable. Another frequent site was on a cross formed by two limbs, often where a dead tree had fallen over on a l1ve one.

The average helght of 76 Cattle Egret nests in 1960 was 7.8 feet (76 nests, range $5.5-12.0, S . D .=1.39)$. Many of the1r nests were placed in elther red maple (33 per cent of all nests) or in buttonbush (29 per cent). Elder was also used frequently (19 per cent of the nests) and wax myrtle and w1llow were used least (12 and 7 per cent, respect1vely).

Cattle Egrets breed in a varlety of sites throughout their extensive range. This specles bullds 1 ts nests in reed beds in East Africa (Mackrarth-Praed and Grant, 1957) and from 50 to 80 feet up in eucalyptus trees in South Africa (Skead, 1956). Whistler (1949) says that In Indla they often nest at considerable helghts. However, in Africa and India and throughout thelr range they most commonly nest at less than 20 feet. In Japan they nest 10 to 20 feet from the ground in the low branches of trees, shrubs, or bamboos (Austin and Kuroda, 1953), and In thelr generalization W1therby et al. (1947), say Cattle Egrets usually nest in trees and bushes growing in water but that they also nest in blg cark-oaks on dry ground, on rocky 1slets, and in b1g trees in towns in Egypt.

\section{Nest Bullding}

Nest material was brought to the females by the males. Th1s was the typlcal sequence: the male landed near the female, stretched his neck, and proffered the twig to the female; the male usually landed quite close to the nest but sometimes had to take a step or two, or 
hop down one more 11mb, befare passing the twlg. The male elevated the crown and back feathers and sometimes the chln feathers as he offered the twig; the female elevated her feathers, took the tw1g, sleeked her plumage as did the male, turned to the nest, and pushed the twig into the nest. The female laid the first few twlgs in a little p1le, but worked later twlgs into the nest by trial and error. She accidentally dropped many. Although W1therby et al. (1947) say that both sexes bulld the nest, Skead (1956) says that one bird gathers the nesting material, but the other does the actual bullding, my observations confirming the latter.

The male flew directly to the upper parts of trees and bushes after delivering a twig to the female. He broke off twigs, but unlike the Snowy Egret never descended to the heronry floor to plck up twlgs lying there. Skead (1956) says that in South Africa they gather mater1al from the ground or pull it from the trees. The dead, brittle twigs were broken off by the earliest nesting Cattle Egrets and Little Blue Herons. The twlgs broken off by later nesting individuals were live and tough. The male spent much time looking for a twig he could reach. He would grab 1t in h1s b1ll, pull back on 1t, jerk 1t, pull back, lean back precarlously flapping with his wings, recover his perch, give it another jerk, and often fail to break it off.

At flrst the males gathered twlgs from the bushes and trees with 10 the heronry. They soon exhausted th1s supply, and started foraging farther from the nest site. By mid-season, Cattle Egrets were gathering twlgs from bushes and trees around the lakeshore and from distant parts of the lake. Late in the 1960 sesson a few males gathered sticks more than a half mile south of Lake Allce and flew back to the lake with them. The birds gathered a few twigs about the heronry throughout the season as the vegetation continued to grow. 
Nest bullding continued for an average of 6.6 days (26 nests, range 3-11 days, S.D. $=1.88$ ) before the first egg was la1d. There was considerable varlation in the rate at whlch stlcks were added to the nest. In some nests a few stlcks were gathered and nothing more was added for several days, whlle in others the bulk of the nest was completed within two or three days. The adults contlnued to add a few twigs to the nest during early 1ncubation; nests were essent1ally complete early in the egg-laylng perlod, and subsequent twigs were added for repalr and maintenance of the nest.

If one member of each pair was not always present at the nest throughout and following construction other herons, which were always on the prowl for nest twigs, dismantled the nest. Many birds added substantially to the1r nests every day up to egg laylag. A few b1rds completed their nests several days before the female la1d the first egg.

\section{Egg Laylng and Clutch S1ze}

Cattle Egret nests were falrly complete when the females laid their f1rst eggs, and they seldom lost these first eggs because of poor nest construction. The esgs were typlcally lald before 9:00 in the marning. The Interval between egg lay1ng was two days; the 1nterval was determined between the first and second eggs 29 times, second and third eggs 38 times, third and fourth eggs 20 times, and fourth and fifth eggs 2 t1mes.

The clutches averaged 3.5 eggs ( 85 clutches, range $1-6, \mathrm{~S} . \mathrm{D} .=$ $0.69)$. The number of eggs in each nest is summar1zed in Table 2. Clutches completed between $m 1 d-A p r 11$ and mld-May averaged 3.6 eggs (64 clutches, range $3-5$, S.D. $=0.58$ ), and those completed between mid-May and mid-July averaged 3.4 eggs (31 clutches, range 1-6, S.D. = 0.99). 
The late clutches thus are both slightly smaller in average slze and slightly more variable in size (see also Table 2), however they are not signiflcantly smaller ("t" = 0.84). Cattle Egret clutch size appears to vary throughout 1ts range, it is given as: three to five In Japan (Austin and Kuroda, 1953), one to three 1n East Africa, three to f1ve in South Africa (Mackworth-Praed and Grant, 1957), two or three in South Afrlca (Skead, 1956), four or flve in India (Whistler, 1949), and four or five, 81x occaslonally, is Given as a generalizat1on by w1therby et al. (1957).

Late broods were not smaller than the early ones. There was no evldence that any of the Cattle Egrets ralsed two broods. Although nesting extended over a long enough perlod to allow a few of the earliest to nest agaln, very few pairs did nest at the end of the season, and they were more likely pairs whlch started late in the first place and falled with their first attempts.

Incubation

Incubation at Lake Allce, as in South Africa (Skead, 1956), was by both sexes. Observations indicate that incubation began in all nests w1th the first eg8. Typically however, one young hatched in each nest the first day. The second day a second one hatched in about half the nests. S1nce the second egg was always lald two days after the first, it follows that if Incubation started when the first egg was lald the second egg should have hatched two days after the first. Effective 1ncubation apparently began the day the first egs was la1d In about half the nests, and the day after the first egg was la1d in the other half. Th1s was probably delayed in many nests because the adults spent much of the first day adding twlgs to the nest. 
Table 2.--Frequency Distribution of Clutch S1ze of Cattle Egrets, Lake Allce, 1960

\begin{tabular}{lllllll}
\hline & \multicolumn{7}{c}{ Cutch s1ze } \\
\cline { 2 - 7 } & 1 & 2 & 3 & 4 & 5 & 6 \\
\hline Total number of nests & 1 & 3 & 41 & 33 & 6 & 1 \\
\hline May 13 to July 15 & 0 & 0 & 28 & 22 & 4 & 0 \\
\hline
\end{tabular}


The average 1ncubation period of the Cattle Egret was 22.9 days (30 nests, range $22-23, \mathrm{~S} . \mathrm{D} .=0.24)$. Incubation was 22 days in two clutches and in the remalning 28 nests required 23 days. According to W1therby et al. (1947) the incubation period is 21-24 days. Skead (1956) gave the Incubation period as 26 days, which would be about the time from the laying of the first egg to the hatching of the last young In clutches of two or three which he observed.

\section{Hatching and the Young}

The young could be heard calling lnstde the egg for a day or two before they hatched. They often plpped the day before they hatched. Sometimes they pipped two, ar rarely three, days befare hatching. The young drled off rapldily. They were covered with a moderate amount of whlte down, and had a falrly well pronounced crown.

The f1rst day of hatching the Cattle Egret nests averaged 1.1 young (49 nests, range 1-2, S.D. $=0.28$ ); 45 of 49 nests contalned one and the other four nests held two chlcks each. The second day of hatchIng the nests averaged 1.6 young ( 41 broods, range $1-3, S . D .=0.58$ ); they averaged 2.1 on the third, 2.6 on the fourth, and 3.0 on the f1fth day. In general terms, the nests averaged one chlck the first day and Increased at an average rate of one every other day thereafter. Th1s correlates with the rate at which the eggs were laid. About half the first-lald eggs hatched one day before, and half hatched two days before the second egg hatched, but all later eggs hatched one every other day.

An average of 3.2 young hatched per nest (73 nests, range 1-5, S.D. $=0.81$ ). The average hatching time was 4.7 days per nest (4I nests, range $1-8$ days, S.D. $=1.83)$. The adults cont Inued to brood the young for several days after hatching started. Skead (1956) also noticed that 
there was little change in adult behavlor when the young flrst hatched. In many neats the last young hatched seven or even elght days after the first one, and the adults were not able to incubate continuously during the day for that perlod of time because the oldest slblings were large and required considerable food. The comblnation of high alr temperature and large stblings was obviously sufflelent to provide warmth to carry the eggs through the last few days of incubation. The "peckorder" that Skead (1956) noted in Cattle Egret broods was probably the simple dominance of larger over smaller nestlings. During mid-day brooding of the young chlcks and eggs conslsted mostly of shading them In practically all the late nests. The parent stood over the nest with the body at a rlght angle to the sun's rays, often with the wing nearest the sun drooped and shading the young.

At first the young were too weak to do more than ifft their heads momentarlly. They spent their time resting and plcking food up from the floor of the nest. After a fow days they could hold thelr heads up and take food directly from the perent's b1ll. From this time on they spent most of the daylight hours sitting up in the nest with the wings partly extended, the b111 open, and the gular pouch flutter1ng. As w1th the Snowy Egret, the young were soon able to reach down Into the parent's gullet and remove food before the parent could regurgltate 1 t.

\section{Mortallty of Eggs and Young}

Adult Cattle Egrets were extremely attentive and seldom lost any eggs from their nests. From egg laying to the day before hatching mortallty was only 3.9 per cent. Occaslonally a predator took all the eggs from a Cattle Egret nest, but these nests could have been ones that had been abandoned already, ar the adults mlght have abandoned 
them when they did lose an egg to a predatar. Very few clutches were so lost. The hatching mortality was 7.0 per cent, and the minimum over-all martal1ty of eggs from laylng through batching was 10.7 per cent.

There was l1ttle loss of nestlings (2.5 per cent) during the first two days that followed the hatching of the last individual. The brood was reduced to 3.0 young (66 broods, range $1-4, S . D_{0}=0.79$ ) at the end of the first week, and further reduced to 2.9 young (52 broods, range $1-4, S . D .=0.80)$ by the t1me the youngest chlck was two weeks old. The differences between the numbers alive at hatching, two days later, one week later, and two weeks later are not slgnlflcantly different, but the number al1ve two weeks after hatching 18 signiflcantly less than the number hatching (" $t "=1.78$ ). The martal1ty of nestlings during the1r first two weeks was 8.2 per cent. The minimum martal1ty from egg laylng through two weeks of age far the youngest nestling was 17.9 per cent.

There was considerable 108 s of young when they started climbing around in the trees. If they climbed into the nest of an Incubating Cattle Egret they were pecked unt1l they left or fell from the tree. Although I never saw the adults k1ll a young bird, I ccaslonally saw blood on the young, especlally thelr wlags, after such encounters. The nest1ng vegetation was low and dense at Lake Al1ce, and young Cattle Egrets that fell to the ground were usually able to get back to thelr nests. Those that wandered about befare attempt1ng to return to the trees frequently fell prey to alligatars. In South Afrlca, young Cattle Egrets that fell to the ground were umable to get back to their nests (50 feet and hlgher) and starved (Skead, 1956). In 1960, at least f1ve 
young Cattle Egrets between three and four weeks old were eaten by alligators around one small pond in part of the Lake Allce heronry. Skead (1956) says that In South Afrlca "eagles" take the young and "cause great consternation in the colontes." Another unusual cause of mortality was the paralysis of many nestlings which occurred only durling one year in the heronry whIch skead (1956) observed.

\section{Little Blue Heron}

\section{Nest Site}

Little Blve Herons built their nests in the territorles established by the male, and they usually butlt them on the perch he had used for courtship. The favared site for both courtshlp and nest bullding was an ald nest. However, Meanley (1955) says the LIttle Blue Herons he studied did not use the old nests that were avallable. At Lake Allce LIttle Blue Herons were often the first birds to move Into and breed in prevlously unoccupled parts of the lake. The males moved into these areas, established territarles that included the few nests of the previous year, using them as platforms where they performed their stretch displays, and preened. Those unable to find such favored sites usually built their nests on small horlzontal limbs wodglag it against the main trunk. Less common nest sites included forks of large horlzontal limbs, places where two branches crossed, or some place where they could lodbe the first few twigs.

The average helght of Little Blue Heron nests in 1960 was 7.2 feet (49 nests, range $4.5-10.5, \mathrm{~S} . \mathrm{D} .=1.41$ ). Hovever, L1ttle Blue Berons had two distinct peaks of nesting activity in 1960: In the early peak, clutches cormpleted before Apr 11 28, the average nest helght was 6.7 
feet; In the later perlod, most clutches completed botween June 10 and June 30 , the average nest helght was 8.5 feet. Ilttle Blus Herons showed strong nest site preferences; they bullt 49 per cent of the 1r nests in red maple and 36 per cent in buttonbush. They bullt few nests in elder (1l per cent) or wlllow ( 4 per cent) and bullt no nests 1n wax myrtle.

According to Howell (1932) Llttle Blue Herons bulld thelr nests In wlllow, wax myrtle, and, in northern Florida, in tit1 (Howell, 1932). W11lows and other bushes (Bent, 1926), buttonbush and swamp privet are used in Arkansas (Meanley, 1955). Box elder, water maple, overcup oak, and eln are sites in Tennessee (Ganler, 1960), and nosts are bullt in catalpa in Oklahoma (Tomer, 1955). Most of the nest s1tes just described are over water or on 18lands, but the catalpa tree heronry in Oklahoma was on dry land. Bent (1926) says that on the wlllow 1slands of the upper St. Johns River in Flarida the Little Blue Herons nest in bushes on the outer edges of the 1slands, from two to four feet above the ground. Howell (1932) says the nests are bullt from four to elght feet above water. In the woods described by Ganfer, most nests were between 16 and 25 feet up. In Arkansas Little Blue Herons bulld their nests closer to the shore than do the other species, and bulld them at an average helght of elght feet (range 3-15 feet) with other nests placed up to 25 feet (Meanley, 1955). In the catalpa woods they nested 9-18 feet above the ground (Tomer, 1955).

\section{Nest Butlding}

The males gathered the nesting materlal, twlgs and small branches, and brought it to the females who bullt the nests, and Meanley (1955) 
reported the males gathering sticks and passing them to the females in Arkansas. At Lake Allce the male plew to nest, and landed close enough to 1 that he could pass the tw1g to the female. The male lovered the head, extended the neck, and polnted h1s b1ll toward the female who reached out and took the twig in her b1ll. The male usually turned around 1mmedlately and left, but would sometlmes remain near the nest and preen or would sometimes move over into the nest with the female. The female turned to the nest with the twig, and if the nest was just being started she would lay the $\operatorname{twl}_{g}$ on top of the others. If the nest was nearly complete she pushed the tw1g into the nest from the s1de. Whlle working twigs into the nest, she frequently dropped them, and at the peak of bullding the ground beneath I1ttle Blue Heron nests was often littered w1th twigs.

The male collected nest materlal by breaking twlgs off bushes and trees. Male Ilttle Blue Herons collected trigs at all levels throughout the heronry, but primarlly from the upper halves of the trees and bushes. In Arkansas, Meanley (1955) found they occaslonally break off tw1gs, but usually gather twlgs from the shallow water beneath the nest. At Lake Allce the males few from tree to tree, grabbing, pulling, shaking, and attempting to break off any one of several twlgs before successfully getting one. Each flew directly to hls territory with the tw18, landed near and usually above the nest, hopped down to the nest, and passed the twig to the female. Because Little Blue Herons nested earlier than the Cattle Egrets, practically all their nests were complete before twlgs became scarce, and the males were able to gather all their nesting material in the general vicinity of their own territary. As they wandered about searching for nesting materlals, the males took twlgs from any 
nests that were left unguarded by other blrds. Only a few twlgs could be pulled from any nest befare the whole thing came apart and fell to the ground.

Nest construction continued into the egg-laylng perlod but was generally completed by the time Incubation started. The bulk of the material was added to the nest before the flrst egg was la1d. The adults warked on the nest for 4.8 days (12 nests, range 3-8, S.D. . 1.41). Meanley's (1955) statement that nest construction requires, "three to f1ve days, occaslonally s1x ar seven days," falls within the range for the Lake Allce birds. Nests were butlt falrly rapldy at a rather uniform rate, but the birds occaslonally had to abandon one site in favor of another a foot ar two distant because the place first selected offered an Inadequate base for the nest. The first egs was often lald in a very small nest, and In such cases the nest was usually completed with two mare days of bullding. Most nests were obvlously "completed" on the thled or fourth day. Stloks added later merely relnforced the structure.

Egg Laylag and Clutch S1ze

The female Little Blue Heron la1d the first egg from three to elght days after starting the nest. Although a small propartion of nests were not complete at that time, eggs were lost through the nest only occasionally. The eggs typlcally were latd befare 9:00 in the marntang. They were lald at a rate of one every 1.7 days ( 48 intervals, range $1-2$ days, S.D. $=0.47$ ). The Interval between laylng the flrst and the second egB was 1.7 days, the 1nterval between the second and th1rd egg was 1.7 days, and the Interval between the third and fourth egg was 1.7 days. 
There was one interval of one day in 12 of the 18 nests that eventually held three or four eggs, in the other $81 x$ nests all intervals were two days, and in one nest with flve eggs the intervals between the first and second and the fourth and fifth eggs were one day. Meanley (1955) seems to have noted that eggs are sometimes lald on consecutive days and not always on altermate days because he says that they are, "deposited on an average of one nearly every otber day."

The clutches contalned an average of 3.7 eggs (58 nests, range $2-5$, S.D. $=0.73$ ). An average of at least 3.8 (56 nests, range 2-6, S.D. $=0.69)$ eggs were laid in nests that eventually held complete clutches, but some were lost before incubation started. The number of eggs in each clutch 18 sumarized in Table 3 . According to Bent (1926) the Little Blue Heron usually lays four or flve eggs, sometimes only three and occaslonally six, and according to Howell (1932) they usually lay four ar five eggs. Meanley (1955) gives an average of 4.04 eggs for 50 nests with a range of from three to flve eggs. Few IIttle Blue Heron clutches were completed between Apr 1126 and May 2l, 1960, any place in the heroary, and there was no new nesting activity In the study ares during this perlod. Clutches completed earlier, from Apr 1l 3 to Apr1l 26, averaged 4.1 eg8s (39 clutches, range 3-5, S.D. $=0.48)$. Clutches completed between May 21 and July 4 averaged 2.9 eggs (19 clutches, range $2-4, S . D .=0.45)$. Th1s alfference 18 also seen in Table 3. The late clutches were signiflcantly smaller, $" t "=9.07$. The reasons why there were no new nesting efforts for a three-week perlod are vague. The small slze of the late clutches is common to many specles and was discussed by Lack (1954), and although the adults brought different food to their nestlings after mid-June, the 
Table 3.--Frequency Distribution of Clutch S1ze of Little Blue Herons, Lake Allce, 1960

\begin{tabular}{lllll}
\hline & \multicolumn{5}{c}{ Clutch size } \\
\cline { 2 - 5 } & 2 & 3 & 4 & 5 \\
\hline Total nest for the season & 3 & 18 & 31 & 6 \\
\hline Apr11 29 to July 4 & 0 & 3 & 30 & 6 \\
\hline
\end{tabular}


explanation for the smaller clutches is unknown. Most of these late nest1ng efforts were apparently renesting efforts.

It 18 highly Improbable that Little Herons ralsed two broods at Lake Al1ce. A few late nest effarts were started about the t1me the parents of the earllest broods finlshed feeding thelr young. Chronolog1cally 1t was barely possible, but it is not likely that only the few pairs nesting earliest might ralse a second brood, and that they could do so Inmediately after the first brood became independent. There were mare early nesting efforts interrupted than were there late nest1ng efforts started.

\section{Incubet1on}

In many nests the flrst egg lald was the only egg whlch opened on the first day of hatching; but by the second day of hatchlng three eggs had usually hatched. It appears then that incubation started the day after the second egg was la1d or the day the third egg was lald. Adult behsvlor at the nest Indicated that they d1d not beg1n to Incubate unt1l after there were two eggs in the nest, and that they nearly always were incubating a nest w1th three eggs. These observations agree w1th Meanley's (1955) observation that incubation virtually always begins after the laylng of the second egg. At Iake Allce, however, the frequent hatching of the first egg one day before the others Indfcates that 1t had recelved at least one mare day of effective incubation than had any of the others.

The 1ncubation period for 19 clutches averaged 22.8 days (range 22-25 days, S.D. = 0.73). E1ght clutches had an 1ncubat1on per1od of 22 days, elght had a perlod of 23 days, one took 4 days, and two clutches 
required 25 days. The two clutches that required 25 days ware the only Plve-egs clutches for which I obtained Incubation periods; but there appears to be no carrelation between clutch slze and duration of Incubation.

Both parents incubated the eggs. Published Incubation periods agree with the Lake Allce data, Meanley (1955) saylag that Incubation 18 done by both sexes and 1822 to 24 days, 22 or 23 days 18 the rule, and Sprunt and Chamberlain (1949) glve the Incubation perlod as 21 to 23 days.

Hatchling and the Young

The young called in the egg for a day ar two befare they hatched. They usually plpped one day before they hatched. Hovever, they occasionally hatched the same day they first plpped, and rarely plpped two or three days before hatching. The young drled shortly after hatching as did young of the other specles. They are covered with a moderate amount of down which 18 white except for the short crest which 18 a dingy, pale brown.

The first day of hatching most nests contalned one young, some had two, and a very few had three. The first day the nests averaged 1.6 chlcks (37 nests, range 1-3, S.D. = 0.69). The second day most nests had three, a few still had one or two and a very few had four; the nests averaged 2.5 young (33 broods, range $1-4, S . D .=0.95)$. The third day the frequency or nests with four increased and the broods averaged 2.9.

An average of 3.2 Little Blue Herons hatched per nest (5l nests, range $1-5, S . D .=1.00)$. Hatching of the entire brood required an average of 3.2 days (31 nests, range 1-7, S.D. - 1.42). The young vere weak 
and Inactive for the first few days, and were unable to ralse their heads more than briefly. Within a few days they could hold their heads up for long perlods, and called frequently. The adults continued broodIng unt1l the young could hold themselves upright. The most obvious change in adult behavior at hatching was an increased restlessness, some Individuals stood up and looked at the young, moving around a great deal. Others changed behavior but little. The young first fed by plcking up food the adults regurgltated into the nest, but later took food from the adult's bill, and at about 10 to 14 days reached down Into the adult's gullet for the food.

\section{Mortality}

L1ttle Blue Herons lost few eggs once they started 1ncubation. The mortality from egg lay1ng unt1l just before hatching wes 3.9 per cent. There was a 108 of 12.1 per cent during hatching. The total mortality from egg laylng through hatching exceeded 15.6 per cent. Meanley (1955) does not give comparable date for the Arkansas heronry he studied, but he says that robbling the nests of stlcks by other herons and egrets 18 the principal cause of egg 108 .

Although an average of 3.2 eggs hatched per nest, there were only 3.0 young per nest two days after the last egg hatched (47 nests, range $1-5$, S.D. $=0.91)$. This 1s not slgniflcantly less than the number at two days ("t" $=0.98$ ), and they were st1ll further reduced to an average of 2.4 by the end of the second week ( 40 nests, range 1-4, S.D. $=0.76$ ), the difference between the last two flgures is slgniflcant ("t" = 2.17 ). Some of the young started leaving the nest at thls t1me. An average of nearly one young per nest ( 0.8 young, 47 nests, range $0-4, \mathrm{~S} . \mathrm{D} .=0.65$ ) 
was lost durlag the two weeks followlng hatchlng. The nestling martallty was 26.2 per cent. Practlcally all these losses were duo to starvation of the smallest and youngest hatchllngs. Young that hatched as late as four or flve days after the flrat young had hatched seldom developed rapldly enough to be able to successfully compete with their older slblings. Of 30 Llttle Blue Heron nests that lost young, 23 nests lost one, and 6 nests lost two, and l lost four. Meanley (1955) says that their nest mates push them out. He also implicates raccoons, house cats and Black Vultures as predators, none of wh1ch appeared to be so at Lake Allce.

Causes of high mortality that occurred when the young left the nest were difficult to evaluate. Most of those that fell out of the trees were able to get back into them. The day after an extremely heavy rainfall, (3.55 1nches on June 18, 1960) I found two nearly dead young on the floor of the heronry. Their feathers were wet and packed w1th mud and thelr wing feathers had been pounded Into the mud by the rain. The next day they were gone and had not returned to the nest tree. One chick about three weeks old was attacked by nearby adult herons of several species when 1 t invaded their nesting territories. It was bleeding on the wing and back and appeared to be very weakened; and It disappeared during the next night.

\section{Louls1ans Heron}

\section{Nest s1te}

Loulsians Herons also bullt their nests in the territorles established by the males. It was usually placed where the male held h1s courtship displays. Th1s 18 probably because the male selected the 
steadiest site avallable withln the territary. The nest site was often an old nest if one occurred in the territory. Such relatively scarce sites were preferred by most other herons at Lake Allce. However, the Louislans Heron was the flrst specles to start nesting and established Its territorles to include most of the few old nest platforms avallable. Blrds renesting later in the season were often able to take over abandoned nests. If the territory did not include an old nest, they usually bullt in the sturdlest place avallable. Loulslana Herons established territarles with comparatively secure perches and seldom lost nests.

The average helght of Loulstena Heron nests in 1960 was 5.7 feet (30 nests, range $3.5-7.5$, S.D. $=0.96$ ). Loulslans Herons bullt 39 per cent of their nests in elder. They also nested frequently in buttonbush (29 per cent) and in myrtle (18 per cent of all nests) but they seldom nested in red maple, or w1llow ( 11 and 7 per cent, respectively).

In Flarida, Loulslana Herons are sald to nest in w1llows, mangroves, buttonwoods, and rushes (Bent, 1926, Howell, 1932). In Texas, Bent (1926) records them nesting in these, and also in cane, mesquite, huslache, and occaslonally in prickly pear. The nest helght in one Texas heronry is given as one to two feet; and in another heronry as 10 to 15 feet (Bent, 1926). Howell (1932) glves the nest helght of Florlda birds as 2 to 20 feet, but on the upper St. Johns River Bent (1926) says they bulld their nests in the middle of the heronries at helghts of 2 to 12 feet, and in the cuthbert Lake heronry they build the Ir nests throughout the heronry at 6 to 12 feet above the ground. 


\section{Nest Buflding}

Nesting material was gathered and brought to the female by the male. When returning w1th nesting materials the male alighted next to the nest and usually a little above 1t. As he settled to the perch and folded h1s wlags he elevated hls algrettes and offered the twig to the female. She elevated her algrettes as the male landed, and took the twig from him. They both then lowered their algrettes. The male occasionally remained at the nest to preen and rest before going after mare twigs. The female Immediately turned to the nest w1th the twig, and by trial and error usually found a place for 1t. Huxley (notes quoted in Bent, 1926) says that in Loulsiana, the male "usually, perhaps always," flnds the st1cks, and the female doos the actual bullding.

Early in the season, nestlng materlal was gathered from the ground beneath the heronry. The male usually plcked up dead twlgs, and often several were plcked up and rejected before one was carrled to the nest site. He occaslonally broke twigs off large fallen I1mbs and small bushes and would wander quite far from the territary in this search. After passing the twlg to the female he immedlately searched for other twlgs, and having found a good place to gather them would fly directly to that spot from the nest. Late nests included twigs with fresh leaves. These could have been broken off by the male, or they could have been wastage from nests of other specles, whlch was not determined. Nest construction was a continuing affalr with Loulstana Herons, but the bulk of construction occurred during a period of four to $81 x$ days, (occasionally up to elght days early in the season, or later as 
short as three days). Usually five days passed before the eggs were 1a1d. The male brought the bulk of the nest materlal during the first three days. By the end of the third day most nests were nearly of their maximal s1ze. The birds added fewer sticks to the nest during the next two days. Durlag this time the nest became more compact as they worked the twlgs 1nto the nest structure, and It acquired a more bowl-like shape. The adults continued to add to the nest during egg laying and Incubation, but the amount of materlal brought in waned as incubation progressed. A bird might grab a nest twlg and j1ggle it or force it farther into the nest whenever it was on the nest.

\section{Egg Laying and Clutch 81ze}

Loulslans Herons lald the flrst egg about four or five days after the nest was started. The nest wes large and nearly complete by this time. Eggs were lald before 9:00 in the morning. The average 1nterval between laylng was 1.7 days (40 1ntervals, range $1-2$ days, S.D. = 0.65). The first and second eggs were laid on consecutive days about half the time and on alternate days about half the time (average 1.6 days), but the frequency of two-day intervals increased with each successive egg. The average Interval was 1.7 days between the second and third eggs and 1.8 days between the third and fourth.

The Loulsians Heron clutches averaged 4.1 eggs (35 nests, range $3-6$, S.D. $=0.66)$. A few egg8 were lost before 1ncubation started and an average of at least 4.3 eggs were lald (35 nests, range $3-9$, S.D. = 1.04). The number of eggs in each clutch 1s show in Table 4. Howell (1932) glves the clutch as three to flve whlch agrees well with the Lake Allce data, but Bent (1926) says they "usually lay four or five 
Table 4.--Frequency D1stribution of Clutch S1ze of Loulslana Herons, Lake Allce, 1960

Clutch Size

\begin{tabular}{|c|c|c|c|}
\hline 3 & 4 & 5 & 6 \\
\hline 4 & 22 & 9 & 1 \\
\hline
\end{tabular}


eggs, sometimes three, occasionally $81 \mathrm{x}$ or very rarely seven" which is more than they lay at Lake Alice. There was an indication that late clutches at Lake Allce tended to be smaller, but only a few late nests were found, not enough to permit any generalization. The Loutsians Heron was the first ardeld to start nesting, and a high per cent of 1ts early nests were successful. Egg laylng was flnlshed in 33 of 35 nests by April 27. The two late clutches were P1nlshed May 2 and May 20. Loulstana Herons did not ralse two broods.

\section{Incubation}

Loufsiana Herons at Lake Alfce seldom Incubated one or two eggs, but were usually incubating when the nest held three or mare eggs. The start of Incubation, which was varlable for all four specles, was most varlable in the Loulslana Heron. The first day of hatching a few nests contalned three young. In some clutches only one chlck hatched on the first day, and in a few of these the pattern of hatching lndicated that incubation started the day before the second egg was la1d. In clutches of five eggs there were usually four chlcks by the third day of hatching, and most of those that did not have four had three. Incubation most frequently started the day before the penultimate egg was 1a1d.

The 1ncubation period for 10 clutches averaged 23.8 days (range 23-25 days, S.D. $=0.60)$. Three clutches hatched in 23 days, $81 x$ clutches in 24 days, and one took 25 days. The 25 day clutch contalned five eggs as did two of the 24 day clutches, but no conclusions can be drawn from the data. The widely given Incubation perlod of 21 days 18 credited to Audubon (1840) by Bent (1926). Both parents incubated. 


\section{Hatching and the Young}

The young called inside the egg for a day or two before they hatched. Typically they plpped the day before they hatched. The adults dropped the empty shells over the edge of the nest. The young dried off quickly. They are covered with a moderate amount of white, dark brown, and almost black down. The down faded sllghtly before the young acquired feathers.

The first day of hatching most Loulslana Heron nests contained one young, but same nests held two or three. They averaged 2.2 chlcks the IIrst day (25 nests, range 1-3, 8.D. = 0.86). The next day most nests held three, a few had two or four, and a very few st1ll had one. They averaged 2.7 chlcks on the second day (23 nests, range $1-4,5 . D .=0.86$ ). On the third day most nests had three or four, a few st1ll had two, and they averaged 3.1. The fourth day they averaged 3.1 young, and flnally on the f1fth day the f1fth young hatched in some nests.

An average of 3.7 young hatched per nest (29 nests, range 2-5, S.D. $=0.78$ ). Hatching took an average of 3.4 days per clutch ( 24 nests, range $2-5, S . D .=1.11$ ). Four was the most frequent number of young hatching, three was next most frequent, and a few broods contained five ar two young. At least one young was lost from every nest in which flve young hatched. Considerlang broods of all ages three was the modal number of young.

Loulsiana Herons brooded cont1nuously unt1l the young were several days ald. Since they bred early in the season they only occasionally needed to shade elther the eggs or the hatchlings. There was l1ttle apparent change in adult behavlar at hatching except that the birds seemed 
to move around on the nest more. Both parents cont1nued brooding. When the young were several days old, by which time the youngest was large enough to hold up Its head, the adults left them alone whlle they both hunted for food. The adults continued to brood the chlcks at night.

Unt1l the young vere a few days old they were unable to hold up their heads more than momentarlly. During this perlod they spent most of their time resting. They fed by plcking up food the adults regurgltated 1nto the nest. After they became able to hold their heads up they were able to take food directly from the parent. By the time they were about two weeks old they could reach 1nto the adult's oullet and selze the food on 1ts way up.

\section{Martal1ty of Eggs and Young}

Although some egg日 were lost before incubation started only a few eggs were lost during incubation. From laylng unt1l just before hatchIng egg mortality was only 3.9 per cent. The hatching mortality was 10.5 per cent, and the minimum mortality during laylng, Incubating, and hatching was 14.0 per cent.

The average number of hatchlings surviving unt1l two days after the last one hatched was 3.4 per nest (30 nests, rango $1-5, \mathrm{~S} . \mathrm{D} .=1.08$ ), this is not slgniflcantly less than the number that hatched (" $t$ " = 1.31). The number was further reduced to 3.1 by the seventh day after batching ( 31 nests, range 1-5, S.D. =0.85), which is not signiflcantly I.ess than the number allve at two days $(" t "=1.09)$. Two weeks after hatchlng an average of 2.8 young survlved (3I nests, range 1-4, S.D. = $0.77)$, which is not algniflcantly fewer than were allve at one week ("t" $=1.63$ ). However, the number of young al1ve decreased signiflcantly 
between the second day after hatching and two weeks ("t" $=2.59)$. Some older young started leavlng the nest when the youngest wos about two weeks old and later estimates of $108 s e s$ were less rellable. One chlck $(0.94)$ was lost per nest (27 nests, range $0-3,5 . D .=0.71$ ) during the f1rst two weeks of nest 11fe, a nestling martal1ty of 18.3 per cent. Most of this $108 s$ was due to the starvation of the youngest chick in many clutches. When the last chlck hatched as late as five or mare days after his oldest slbling he started nest life at a severe disadvantage. Whlle the young were small and feeble the adults regurgitated food onto the floor of the nest from whlch the young plcked it up. When two or three of the nestlings developed to the polnt where they went to the parent, reached down Into 1 ts throat and took the food, the nestling only strong enough to plck food off the nest floor usually got none. Typically only one young starved in a nest (17 of 19 nests in which young starved) but in two nests two did; and in about one out of every three nests none starved.

Another peak in martallty occurred when the young left the nest and started climbing about in the bushes and trees. In spite of their agllity and tenaclty a few fell to the ground, but at Lake Alice where the vegetation was low and bushy most of those Individuals got back into the nest trees. Occasionally one became hung in the trees. One I found dead In 1960 had fallen during a storm from the top of a particularly hlgh nest and landed on 1ts back in a narrow fork of a branch where It ded. Bent (1926) also found young that had become entangled in the vegetation and died, but he also notes that the young climb and swim well. 
FEED INO

A cursory comparison of the feeding behavior of the herons on Payne's Pralrie and in other feeding areas around Gainesville indicates that these birds are all feeding essentlally the same way; that 1s, they are wading around in shallow water catching and eating small animals. The notable exception is the Cattle Egret which regularly feeds in company with cattle on hlgher and usually drler ground. However, any comparative generallzation on their foods must be based on an analysis of food hablts.

When they become exclted or are disturbed, young herons often regurgltate their last meal, which they cast up as a pellet. By systematically collecting these pellets it is possible to acquire a series of heron meals without collecting the birds. The technique has two distinct advantages. (1) Because a large serles of pollets is potentlally arallable, the collector can reject pellets which show advanced or even moderate digestion, and (2) especially with less comon specles, pellets can be repeatedly taken from the same individuals. When the heronry is full of flightiess young it should be an ecologically signiflcant time to study the food habits of the herons, because in arder to feed themselves and their young the adults must gather substantlally more food per day than at any other time of the year. 
Food apparently is abundant in the Gainesville region during the time of year the adults were feeding young because at that time plant growth was rap1d, temperatures were hlgh, and water levels were up. In spite of a probably adequate supply of food, an averago of nearly one young per nest starved to death in nests of three of the four heron specles studled. The adults' need for food for themselves and their ravenous young exceeded their food catching ab1l1ty. It seems reasonable to assume that the birds were operating near their maximal efficlency. If this is true the birds were probably catching the kind of food they could catch the most of and vere searching for it in the places where it was most often avallable to them. Differences in feeding behavior and in food habits would probably be amplifled during this perlod of stress whlle the adults are feeding young.

\section{Feeding Behav1ar of Adults}

The feeding behavior of the varlous herons was otrikingly similar. In most of their feeding activities they employed certain basic techniques which are cormon to all specles. Each specles employed 1ts own varlations of these techniques and the frequencles with which each of the several techniques was used varled among the four specles.

The Ardeldae are oppartunistic birds, not only as a group, but also as Individual species and as individuals. They take advantage of a w1de varlety of food sources and employ a varlety of feeding patterns to catch food. They are quick to take advantage of an abnarmal bounty, and groups composed of several specles would gather around any temporary concentration of food. Although there are many interesting variations, practically all feeding behavior of adult herons around Galneavllle falls 
1nto three general, though not necessarlly distinct categories if

Stand and Walt; (2) Wade or Walk Slowly; and (3) Active Pursult. The first two categarles (names from Meyerrlecks, 1960) are speclfic types of feeding bohavlor and are typlcal of the herons. These two types show several modiflcatlons; but the more unusual and dramatic means of gathering food are mostly varlations of Act1ve Pursult.

In the Stand and Walt type of feeding, the heron finds a Ilkely place, poses his body in readiness, and remsins motionless. The heron remains immoblle and eventually makes a strike if food approaches; if not it moves to a new place. The body may be held low and horlzontal with the ankles flexed and the neck slightly wlthdrawn in a soft "s" curve; or the body may be held upright, the feet and legs straight, and the neck extended. Herons w1ll hold these positions for many minutes, but may sometimes change from one of them to the other.

The Walk ar Wade Slowly type of feeding has many elements in comon with the Stand and Walt type, and resembles a slow moving variant of Stand and Walt. Walk or Wade Slowly 18 the fundamental stealth technique and is an important part of the foeding repertolre of many herons. The body may be held horlzontal with the nock slightly withdrawn and the b1ll pointed forward; or the body may be upright with the neck stralght and the b1ll polnted dowaward at about a 45 degree angle. The body, neck and head are usually held rigld as the heron moves, but the neck sometimes bobs slightly wlth each step, or just before making a strike the head may be withdrawn slightly or it may be undulated s1deways. As the bird moves, each foot is lifted, extended, and lowered quite deliberately; the body is simultaneously moved smoothly forward. The bird may "freeze" just before a strike. Blrds 
hunting by the stand and Walt technlque often feed in the Wade and Walk Slowly technique whlle they are moving from one stand to another. Active Prosult includes Melnertzhagen's (1949) type, D1sturb and Chase; but the most frequent farm of Active prosult in the Gainesville reglon is simply walking or running in shallow water, chasing flsh and making strikes here and there. A frequent ploy of several species is to walk through flelds, or elong the edge of a pond, ar any l1kely place catchlng Insects, frogs, or Plsh that Ilush at the heron's approach. Thls differs from Wade or Walk Slowly in that the body is not held horlzontal or r1gldy, the neck is not necessarlly held rigld but typlcally moves forward and backward wth each step; In other wurds the bird is not "sneaking up" on anything, but only catchlag what it sees and this 18 most often something which 18 moving out of the heron's way. The birds use many other types of Active prrsult, and these form the basis of the many notes published on "unusual" heron feeding behavior; but these more unusual feeding patterns are used only infrequently by the Lake Allce blrds durlang the breeding season. Reaching down and taking food from the water whlle on the wing (Hovering of Meyerriecks, 1960) 1s one of the mare frequent of the ge unusual types, and has been reported in the Gainesville area (D1ckinson, 1947).

\section{Snowy Egret}

Adult snowy Egrets employ the stand and Walt techniques of feeding mare than any other feeding method. They also comonly feed by use of the Wade ar Walk slowly technique, sometimes feeding thus in grasslands away from water. Durlag the sumers Snowy Egrets ocasionally assoclated with cattle. They would walk along near a cow and catch prey disturbed 
by it very much the way Cattle Egrets feed. While with cattle, snowy Egret behavior appeared to be intermediate between merely walking along and flushing prey and Wade or Walk Slowly. Snowy Egrets, more often than any of the other herons, fed by some form of Active pursuit. They would frequently dash about through very shallow water twisting, turning, stopping and taking off in new directions, striking here and there at the f1sh. Snowy Egrets would often interrupt more deliberate types of hunting to chase after fish in shallow water and sometimes would run along a fairly steep canal or stream bank.

Snowy Egrets are soclal feeders and many Individuals would gather to feed in a small area where there was a local abundance of food. Groups of 5 to 25 or sometimes more, often congregated around culverts and along small streams following heavy rains and a rise in the water level.

Young Snowy Egrets readily regurgitated their last meal when disturbed. Nestlings only a few days old did not become as distressed as did one to two week old young when they were disturbed, and they did not usually regurgltate. If one sibling was much less developed than his nest mates, he often ate the food h1s older and more exc1table slblings regurgitated into the nest. Snowy Egret pellets were compact and held together rather well. If the young had been fed recently, each typically produced two pellets when disturbed.

The contents of the 50 analyzed pellets were: flsh 87.8 per cent by volume, invertebrates 7.1 per cent, and amphiblans 4.8 per cent. Table 5 lists the prey taken, the total number found in all 50 pellets, and the per cent of the total volume of each prey 1tem. A total of 46 amphiblans were eaten and 35 of them were tadpoles. These were particularly small tadpoles and taken altogether they comprised only 2.9 per 
Table 5.-Analysis of Fifty Pellets Regurgitated by Young Snowy Egrets

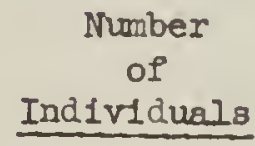

DVVERTEBRATES

Ol1gochaeta Astacldae

Palaemonetes spp. Zygoptera An1soptera (5 nymph) Locust1dae

Tett1gon11dae

Gryll1dae

Hydroph1l1dae

Cor $1 \times 1$ dae

Arachnida
1

6

7

18

188

99

32

15

4

1

19

10

14

2

1

42

2

12

15

21

37

456

224

195

8

1

9

3

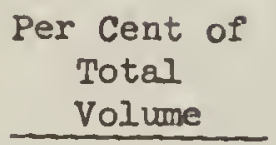

tr.

0.70

0.28

0.06

1.00

2.78

1.47

0.47

0.17

0.04

0.04
Gambus 1a afrinis

Jordanella for1dae

Lepomis macrochirus

Leptolucania ormata

Lucania goode 1

Micropterus salmoldes
9

1.21

1.06

1.28

0.43

0.85

1.08

1.49

5.31

8.29

1.06

6.80

36.14

3.08

20.83

2.34

0.04

0.21

1.23 
cent of the total diet. A few cricket frogs ( 10 Acris gryllus) and one leopard frog (Rana piplens) were taken.

Grasshoppers and crickets (Locust1dae, Tett1gonildse and Gryllidse combined, 4.8 per cent) were only about as important in the over-all diet as were the amphiblans. Most of the pellets contalned a few Insects, and 2 of the 50 contalned no fish but were composed entirely of insects and amphiblans. Dragon-flles (Anlsoptera) were also important Invertebrate food; five nymphs and 13 adults belng taken. A few crayflsh and fresh-water shrimp (Astacldse and Palaemonetes spp.) were included, especially early in the season.

Mosquitofish (Gambusia affinis) was the most important as well as the most numerous prey taken. Fagfish (Jordanella floridae) was second most important. Each of the other prey specles was much less important In the total diet than were these two. Redfin plckerel (Esox americanus) was third, the golden topminnow (Fundulus chrysotus) was fourth, and the banded sunfish (Enneacanthus obesus) was iffth in over-all importance. Six other specles were less important, comprising from 1.1 to 3.1 per cent of the diet. One of these, the least killifish (Heterandria formosa) was the second most frequently taken prey species, 224 indiv1duals were included in the 50 pellets.

The pellets averaged 29.0 Individual prey 1tems. They included an average of 0.9 amphiblans, 7.6 invertebrates, and 20.5 11sh. The most Important prey species, mosquitofish, flagflsh, redfin plckerel, golden topminnow, and banded sunfish, comprised 77.2 per cent of the total diet. Mosquitofish were included 456 times in the 50 pellets and the least killifish was the second most numerous prey with 224 individuals taken. In addition to the 50 pellets discussed above, at least 200 other pellets 
were studled in the heronry, but were not collected, and another 24 pellets that were collected are not included in the analysis. These additional gross observations tend to verffy the preceding observations. According to Baynard (1912), 50 pellets regurgltated by young Snowy Egrets at B1rd Island, Orange Lake, contalned 120 small suckers, 762 grasshoppers, 91 cut-worms, 2 small lizards, 29 small crayfish, and 7 small moccasins. Because Snowy Egrets from Orange Lake feed in places similar to those where the Lake Ailce birds feed, it is difflcult to explain the differences in food. Baynard's taxonomic categorles are too vague to allow careful comparisons.

\section{Cattle Egret}

Durlag the breeding season Cattle Egrets fed In grasslands and open meadows, and although they occaslonally fed in wet places, they mostly fed away from water. They fed by walking along near the head or side of a grazing cow and caught prey flushed by the cow. However, they would occaslonally wander from cow to cow, or even less frequently they would take short excursions away from a cow, and at these times they caught food they disturbed themselves. Individual Cattle Egrets would occasionally feed by themselves, Independent of large ungulates, but although frequently noted durlng the winter this method of feeding was relatively uncommon during the breeding season.

Cattle Egrets are social birds and nearly always fed in small groups. Early in the season they usually fed in groups of 5 to 25 Individuals, but in the middle of the nesting season, when many of the adults were feeding young, they most often fed in small groups of up to five or six individuals. 
Young Cattle Egrets readlly regurgltated their last meal when they were disturbed, and they were more eas1ly disturbed than were the other species. When one young started regurgltating, the other young in the tree immediately started regurgltating, and 25 or 30 pellets would quickly rain down out of a tree. The pellets appeared to be composed almost entirely of grasshoppers with an occasional small frog or snake. The pellets were very neatly packed and were held together by mucous. If they had been fed recently, most young Cattle Egrets would produce two pellets.

The 50 pellets studied were composed of invertebrates 63.2 per cent by volume, amphibians 32.3 per cent, and rept1les 4.4 per cent. The analysis of the 50 pellets on which this discussion is based is presented in Table 6. Reptiles are relatively unlmpartant, only three snakes are included in the 50 pellets.

Amphiblans were an important part of the diet of young Cattle Bgrets. The 50 pellet sample included 101 frogs and toads. The leopard frog was the most important amphiblan volume-wloe although it involved only 23 Individuals as compared with 69 individuals of the volumetrically second ranked crlcket frog. One eastern spadefoot (Scaphlopus holbrook1) was included. Blght other individual amphiblans were recorded: four treefrogs (Hyla spp.), two narrow-mouthed toads (M1crohyla carolinens1s), and two unldentifled frogs. Together these elght individuals contributed only 2.0 per cent to the total diet. These, as well as the spadefoot were probably accidental and incldental in the diet.

Short-horned grasshoppers (Locust1dae) are the most 1mportant prey of Cattle Egrets. Locustids were found in 48 of the 50 pellets. The other two pellets were each composed of one large leopard frog. Crlckets 
(Gryll1dae) were the second most impartant 1nvertebrate prey, but contributed less volume to the det than did leopard frogs. The third most Important 1nvertebrate, long-horned grasshoppers (Tett1gon11dae) were less important than even the crlcket frogs. Collect1vely, the orthopteran 1nsects contributed 56.6 per cent of the diet by volume. Sp1ders (Arachnida) were taken regularly; 88 were included in this sample. The other invertebrate groups (Table 6) each contributed less than 1 per cent of the diet and appeared to be taken accidentally. The pellets contained an average of 34.1 prey 1 tems: 0.1 snakes, 2.0 amphib1ans, and 32.0 invertebrates. The four most impartant prey groups, short-horned grasshoppers, leopard frogs, cr1ckets, and crlcket rogs, comprised 78.8 per cent of the total diet.

In addition to the 50 pellets discussed at length above, 50 more were collected, and about 500 more pellets were studied in the heronry, but not collected. For the most part these observations essent1ally verlfled what has been already sald and only add a few specles to the 11st of prey. The most unusual pellets found were a group of about elght pellets collected on June 23, 1960. They were composed ent1rely of 30 to $50 \mathrm{~mm}$, terrestrial beetle larva (Caleoptera).

Except for occaslonal single-stomach analyses, there appear to be no previously reported quant1tative reports on Cattle Egret food. The1r det is described as very varled, practically omalvarous (MackworthProed and Grant, 1957). Other than this one repart, the Cattle Egret 1s recognlzed as primarlly beling a grasshopper feeder. Grasshoppers are noted as being of Plrst Importance in Indla (Wh1stler, 1949), in South Africa (Skead, 1956), and throughout 1ts range (W1therby et al., 1947). 
Table 6.--Analysis of Flfty Pellets Regurgitated by Young Cattle Egrets

\begin{tabular}{cc}
$\begin{array}{c}\text { Number } \\
\text { of }\end{array}$ & $\begin{array}{c}\text { Per Cent of } \\
\text { Total } \\
\text { Volume }\end{array}$ \\
\hline
\end{tabular}

IVVERTE BRATES

Zygoptera
An1soptera
Locust1dae
Tett1gon11dae
Gryllidae
Coleoptera
Elater1dae
Curcullon1dae
Diptera
Taban1dae
Lep1doptera
Arachnida

$\begin{array}{rr}1 & 0.01 \\ 5 & 0.58 \\ 679 & 36.21 \\ 279 & 6.85 \\ 523 & 13.50 \\ 10 & 0.17 \\ 1 & 0.01 \\ 2 & 0.01 \\ 3 & 0.12 \\ 5 & 0.54 \\ 2 & 0.12 \\ 88 & 5.15\end{array}$

VERTEBRATES

$\frac{\text { Scaphiopus holbrook1 }}{\text { unldentifled frogs }}$
un1dent1f1ed Hyl1dae
Acr1s gryllus
Hyla spp.
Rana p1p1ens
M1crohyla carolinens 1s
Thamnoph1s saur1tus
Thamnoph1s $\frac{\text { slrtal1s }}{\text { Tant1lia coronata }}$

$\begin{array}{rr}1 & 1.25 \\ 2 & 0.83 \\ 2 & 0.42 \\ 69 & 13.29 \\ 2 & 0.42 \\ 23 & 15.78 \\ 2 & 0.42 \\ 1 & 2.08 \\ 1 & 1.66 \\ 1 & 0.62\end{array}$


Most reports on 1 ts food habits describe the beneflcial aspects of Cattle Egrets removing ticks from grazing animals, but skead reparts that in South Africa the Cattle Egret only rarely removes engorged, consplcuous t1cks from cattle even when the ticks are abundant, and no ticks were found in Lake Allce pellets. Besides a wide varlety of Insects, Cattle Egrets eat arachnlds (Solfuges et al.), centipedes, frogs, toads, clawed toads (Xenopus spp.), 11zards, and mice. There Is even one second-hand repart of a Cattle Egat eating a bird (Zosterops spp.) in South Africa (Whistler, 1949, Skead, 1956, and W1therby et al., 1947).

\section{Little Blue Heron}

The principal feeding technique employed by I1ttle Blue Herons was the Wade or Walk Slowly, but they also used the Stand and Walt technique. L1ttle Blue Herons would frequently "freeze" whlle wading, they would slowly lower the head and neck, then strike. Although a few Indiv1duals fed far from water, espec1ally late in the season, most Little Blue Herons fed in water a few Inches deep around the edges of ponds and on the prairies. The Little Blus Heron did not feed in social groups as often as the 8nowy and Cattle Egrets did, but several Ind1viduals often fed in the same general area.

Young Little Blue Herons readily regurgitated their last meal at the least disturbance. The very young somet1mes dropped the pellet into the nest and later re-ate 1t. Oader Individuals, generally, spowed a rather neat pellet over the edge of the nest, or, later, from their perch on a limb. These pellets appeared to be composed of a wide varlety of food stuffs. A conspicuous feature was the frequency with which relatively large prey 1toms were eaten. A redfin plckerel of 
$12 \mathrm{~cm}$. or more, or a bullfrog (Rana catesbelana) wtth a snout-vent length of 6 to $8 \mathrm{~cm}$. frequently composed the entire pellet.

The contents of the 50 Little Blue Heron pellets was: amphiblans nearly 54 per cent by volume, $11 \mathrm{sh} 32.5$ per cent, Invertebrates 12 per cent, and reptiles nearly 1 per cent (see Table 7 far detalled analysis). Reptiles were represented by two snakes.

Craypish and splders were the only invertebrates that contributed substantially to the total food. Most of the spiders, dystiscsids, and orthopterans listed on the table were from 10 pellets collected on June 10 and 13. These mid-June pellets were also unique in other ways and are discussed later.

The golden topminnow was the most important fish prey; it comprised nearly as much volume as the other elght flsh species comblned. The very similar banded topminnow (Pundulus clngulatus) was second in Importance, and the least kfll1P1sh was third. Although the least kllliflsh was slightly less impartant volumetrically, in the diet of the L1ttle Blue Heron young than was the banded topminnow, it was noted 10 times mare often than was the banded topminnow. The other six species of f1sh eaten each contributed from 1.0 to 2.6 per cent of the total volume of food.

Large ranid tadpoles (Rana spp.) and adult bullfrogs were the two most important prey in this sample of 50 pellets. Although the sample included 27 ranid tadpoles, the four bullfrogs nearly equalled them in volume and together they comprised 34.1 per cent of the diet. Leopard frogs were about half as Important, and the green treefrog (Hyla c1nerea) was fourth in 1mportance. Small unldentified ranids and one p1g frog (Rana gryl10) were next in importance. Six newts (Diemictylus 
Table 7.--Analysis of Fifty pellets Regurgitated by Young L1ttle Blue Herons

\begin{tabular}{cc}
$\begin{array}{c}\text { Number } \\
\text { of }\end{array}$ & $\begin{array}{c}\text { Per Cent of } \\
\text { Total } \\
\text { Volume }\end{array}$ \\
\hline
\end{tabular}

TIVERTEBRATES

HLudinea

1

0.02

Astac 1 dae

6

Palaemonetes spp.

An1soptera (5 nymph)

15

Locustidae

Tettigonildae

11

Gryll1dae

Gryllotalpidae

Ephemer1dae

Coleoptera (Iarvae)

Dyst1scsdae

Belostomat1dae

Hydroph1]1dae

Tabantdae

Arachnida

Diemictylus viridescens unidentified tadpoles

Hyla spp.

HyIa cinerea

0.18

unldentifled Rana spp. tadpoles

0.59

2

4.73

Rans spp.

$\overline{\text { Rans }}$ catesbelana

Rana Bryl10

Rans p1piens

Seminatrix pygaea

Thamnoph1s sirtalis

Chaenobryt tus gulosus

Enneacanthus obesus

Esox amer Icanus

27

17.15

2.60

16.95

2.37

7.88

0.69

0.08

2.60

0.99

Fundulus chrysotus

2.37

Fundulus clngulatus

14.78

Gambusla affinis

4.53

Heterandr Ia formosa

Jordanella fiorldae

1.58

3.15

M1cropterus salmoldes 
Virldescens) were found in pellets from three different nests. Therefore, this supposedly noxious amphtblan was of moderate but regular occurrence in the diet of young Little Blue Herons at Lake Alice.

The pellets averaged 8.9 prey items and were composed of an average of 3.0 invertebrates (Including 1.5 spiders), 1.5 amphiblans, less than 0.1 reptiles, and $4.3 \mathrm{flsh}$. The most 1mportant prey in volume were: ranld tadpoles, bullfrogs, golden topmlnnows, leopard frogs, crayfish, green treefrogs, banded topminnows, and spiders, in that arder. These elght forms comprised 75.1 per cent of the diet. Three 1tems stood out as belng of prime impartance: tadpales, bullfrogs, and golden topmtanows.

Many additional pellets, at least 200 , were studled in the heronry but were not collected or preserved. These pellets verifled the material collected and added one very lnteresting observation. Late In the season, from mid-June through July, when few young Little Blue Herons remaln in the heronry, there was a major shift in their food. Flsh became much less inpartant; tree frogs, spiders, and arthopterans became predominate. The general trend was away from aquatic and toward mare terrestrial prey. Many adults fed in open frasslands and pastures during mid-summer. Little Blue Herons wading through the grass and "peering over" in their typical Wade or Walk slowly technique were as frequently seen as those wading in water.

Baynard (1912) analyzed the contents of 50 pellets regurgltated by young Little Blue Herons at Orange Lake. They contalned 1,900 grasshoppers, 37 small frogs, 149 cutworms, 8 lizards, and 142 small crayfish.

E. A. Chapin analyzed 46 Ifttle Blue Heron stamachs (Hovell, 1932) and although the source of the birds was not stated the stomachs 
were probably from several localities and probably collected throughout the yoar. Crustaceans (princlpally crayflshes) composed 45 per cent of the total food, small flshes (mainly minnows and k1llifishes with a few catfishes and sunflshes) composed 27 per cent, insects composed 16.5 per cent and frogs, small snakes, and turtles made up 8.5 per cent. Meanley (1955) analyzed 50 Little Blue Heron pellets whlch he collected in Arkansas. He presented hls data as frequency of occurrence. A wide varlety of Insects, primarlly aquatic forms, were eaten. Frogs, especially leopard frogs, appear to have been quite impartant (found in 14 of 50 pellets). Crayfish were very Important (12 pellets). F1sh appear to have been less important, only a few specles were taken: Lepom1s spp. (7 pellets), Esox spp. (2 pellets), and undetermined fish (6 pellets).

\section{Louts Lans Heron}

During the breeding season Loulslans Herons usually fed by stealth, both the Stand and Walt, and Wade or Walk Slowly technlques belng used. In addition to feeding in ponds and on the prairles, Loulsians Herons were often seen standing Immoblle along the edges of canals and ditches. When wading they often held the body parallel to the water, and the head slightly retracted, and the neck shortened in an "s" curve. They typically waded in deep water and often waded in water so deep that it came up to their thighs, and sometimes to the belly.

The Loulsians Herons occasionally feed by employing some form of the disturb and chase technique. A Loulsiana Heron would run through shallow water herdlag $\mathrm{flsh}$ toward shore and trylng to prevent the ir escape to deep water by wavlag 1 ts wings. It sometlmes hovered or flew low across 
open water and reached down lato the water with the b111 to grab something as $1 t$ flew by.

In the Galnesville area the Louislans Heron is a solitary feeder. Feeding Individual were widely scattered across the prairles and many of them fed along streams and in ponds away from the prairle.

Young Loulsians Herons regurgitated their last meal much less readlly than did young of the other specles at Lake Allce. When disturbed, the older young readlly moved out of the nest and climbed up into the tree, but they often falled to regurgitate. Sometimes they could be forced to regurgltate by shaking their tree, yelling, banging on the limb and generally annoylng them for 5 or 10 minutes, but most of the time this too falled. When they did regurgitate they did not usually produce a neat pellet, but typlcally scattered individual flsh about the ground beneath the tree. It was often impossible to collect more than a few pellets from a brood throughout 1ts whole nest IIfe.

The 50 pellets were composed of 11 sh, 95.4 per cent by volume, varlous 1nvertebrates, 4.2 per cent, and amphiblans, 0.2 per cent (see Table 8 for a detalled analysis). Only one frog, a crlcket frog was included in the 50 pellets. Thls one recard shows how unlmpartant amphlblans were in the diet of young Loulslans Herons, and frogs are here regarded as accidental.

The only invertebrates of importance in the over-all diet were odonates. Of 58 invertebrates eaten 28 were dragon-111es and 8 were damsel-flles (Zygoptera). Together they represented 3.2 per cent of the total dlet. One of the dragon-flles was a nymph and the other 27 were adults. Because of their long membranous wings these insects were 
Table 8.--Analysis of Fifty Pellets Regurgitated by Young Loulslana Herons

\begin{tabular}{cc}
$\begin{array}{c}\text { Number } \\
\text { of } \\
\text { Individuals }\end{array}$ & $\begin{array}{c}\text { Per Cent of } \\
\text { Total } \\
\text { Volume }\end{array}$ \\
\hline
\end{tabular}

ARTHROPODA

Palaemonetes spp.

Zygoptera

2

8

Anlsoptera (nymph)

Tett1gonildae

Gryllidae

Belostomat 1 dae

Hydroph111 dae

Dyst1sesdoe

Diptera

Arachnida

28

0.23

0.25

2.92

0.20

0.17

0.20

2

0.03

1

0.08

1

0.03

1

0.08

\section{VERTEBRATES}

Acr1s gryllus

Chaenobryttus gulosus

Elassoma spp.

Enneacanthus glorlosus

Enneacanthus obesus

Fundulus chrysotus

Fundulus clngulatus

Fundulus nott1

Gambusia affinds

Heterandria formosa

Jordanellae florldae

Leptolucanla armata

Lucanla goodeI

Micropterus 6almoldes

Molliensa Iatipinna

Pomoxis ni gromaculatus

1

0.17

9

30

1

1

81

19

8

205

143

210

1

4

5

11
1.27

0.79

0.57

0.42

22.37

7.93

1.13

13.88

4.53

36.82

0.08

0.11

1.98

2.83

0.91 
conspicuous in the pellets. Their occurrence was sufficlently frequent to preclude the assumption that they are taken rarely or by accident, as 1s assumed for the other 1nvertebrates. It would be interesting to learn whether they were taken opportunlstically or whether the birds made a concerted effort to catch them. Their inclusion in the regular diet may be of further signiflcance in understanding the Loulsiana Heron's total ecology. The other 22 invertebrates showed wide varlety and altogether comprised 1.0 per cent of the food.

The flagflsh was by far the most impartant prey species taken. Mare 1ndividual Plaglish, 2l0, were taken than any other species. Golden topminnows were extremely lmpartant in the diet although only 81 of them were included as opposed to 205 individuals of third in Impartance mosquttofish. The banded topminnow was fourth in 1mportance, and the least k1llifish was a relatively poor flfth in importance although a total of 143 individuals were taken. Sallein mallies (Molliensa latiplnna), Pingerling largemouth bass (M1cropterus salmoldes), warmouth (Chaenobryttus gulosus), and starhead topminnows (Fundulus nott1) composed from 2.8 to 1.1 per cent of the det and were next in importance. The remalning seven floh species each contributed less than 1 per cent to the diet and involved from one to four individuals each except for 30 Individual pygmy ounfish (Elassama spp.).

The pellets averaged 15.8 food 1tems: amphiblans less than 0.1 , Invertebrates 1.1, and f1sh 14.6 Individuals. The three most impartant prey species, Hagf1sh, golden topminnow, and mosquitofish, comprised 73.1 per cent of the diet. 
Young Louislana Herons regurgltated so infrequently that probably no mare than another 50 pellets were seen but not collected in the heronry. These observations generally substantlate what is written above, and none of these other pellets contalned frogs.

Baynard (1912) analyzed 50 pellets regurgitated by young Loulslana Herons at Orange Loke and found 2,876 grasshoppers, 8 small frogs, 17 cutworms, 6 11zards, and 67 small crawflsh. These results are Inconsistent w1th my flnding at Lake Allce and cannot be explained. The findings of E. A. Chapln (Howell, 1932) who analyzed 48 Loulstano Heron stomachs, were more consistent with my data. Although not stated the stomachs he analyzed were probably collected at all seasons throughout their range: k1111f18h composed 68 per cent of the total food in these stomachs, crustaceans (mainly prawns and a few crawflsh) composed 20 per cent, and the balance included clam worms, splders, weev1ls, grasshoppers, glant water bugs, dragon flles, water beetles, and ground beetles. 


\section{COMPARIBON OF REPRODUCTIVE HABITS OF THE SPECIES}

The breeding hlstories of Snowy Egrets, Cattlo Egrets, L1ttle Blue Herons, and Loulslana Herons are quite simllar, but there are differences In the detalls and these vary from the most trivial to same of real ecologlcal slgnificance. Some of these differences amongst specles are the direct result of their 1nterspeciflc relationsh1ps with in the heronry durlag the breeding season, and others are the result of differences In the total blology of the species. Unfartunstely there are practically no qualitative studies on any phase of the blolosy of these blrds with wich the data from lake Allce can be related. In this chapter, the breeding of each of the four most abundant species at Lake Allce will be compared.

\section{Nest Site}

In 1958 , the varlous species of herons appeared to be selecting slightly different nest sites. The result of these differences was a vertical stratiflcat1on of the nests. In 1958, Snowy Egrets nested at lower and more exposed sites than did the other specles. Most of thelr nests were between three and five feet above the heronry floor, with a few up to a maximum of about ten feet. The birds bullt their nests around the edge of the heronry and around openings in the vegetation throughout the middle of the heronry. Llttle Blue Herons bullt the Ir nests higher than did Snowy Egrets, mostly around ten feet and occaslonally 
still higher. Ifttle Blue heron nests were always bullt in better sheltered, sturdier appearing locations than were the Snowy Egret nests. Many Little Blue Heron nests were bullt agalnst the main trunk of the nest tree. The Loulsiana Heron nested at helghts of 2 to 5 feet, much lower than any of the other species, but in contrast to the snowy Egret, the Loulsiana Heron nests were always in well sheltered places. Cattle Egrets started nesting in the middle of the heronry in the denser vegetation of the larger maples. The1r nests were usually from 4 to 8 feet above the heronry floor in a varlety of sites. Later in the season as the heronry spread, Cattle Bgrets started nesting around the edge and openings of the new heronry as well as in the midale. It appeared that Cattle Egrets were selecting about the same type of nest sites as the Snowy Egrets did earlier in the season and that they differed from the snowy Egret sites only in belng alightly higher. The net result of this strat1fication was a reduction of interspeciflc competition.

In 1959, there did not appear to be any really systemat1c stratification of nests at Lake Alice. Most Loulsiana Herons nested low In the bushes and some Cattlo Egrets appeared to nost higher than did any of the other spec1es. For the most part there appeared to be so mich overlap, so many birds nesting from four to $81 x$ feet above the heronry floor, that there was littlo effective separation of the species.

In 1960, more detalled observations were made. The belghts of all nests in the study area and the species of all nest trees or bushes were recorded. The helghts of the nests revealed some interesting features. 8nowy Egrots and Loulslans Heron nests were consistently the lowest; nests of both these specles averaged 5.7 feet above the water or ground. 
Cattle Egrets nested substantially hlgher and thelr nests averaged 7.8 feet above the heronry floar. The Ilttle Blue Herons nested at an average helght of 7.2 feet throughout the season. The difference in nest helght between Cattle Egrets and Itthle Blue Herons wos signiflcant (" $t "=2.08$ ). As polnted out earlier there was a substantial difference in clutch size between early and late neoting Ifttle Blue Herons. The L1ttle Blue Herons that completed egg-laylng by Apr 1128 bullt their nests at an average helght of 6.7 feet, but those that completed thelr clutches after Apr 1128 nested at an average helght of 8.5 feet. There was an obvlous trend for the earllest breeding herons, regardless of species, to establish territarles whlch included the lowest nest oltes. These low sitos tend to be sturdier than the high sites. The situation was sowewhat confused by I1ttle Blue Herons, because even the early nesting palrs selected sllghtly higher sites than did the contemporaneous Snowy Egrets and Loulslana Herons. However, the primary factar causing the strat1flcation appears to have been the differences in the time of nesting. The general trend belng for the earliest nesting pairs to build their nests in the lowest, and probably sturdiest sites avallable and for later nesting individuals to bulld thelr nests higher.

In 1960, the heron nests at Lake Allce were built only in shrubs or trees. The birds built their nests in red maple, buttonbush, elder, myrtle, or wlllow. Red maple was the most important mest site; 37.5 per cent of all heron nests were placed in red maple. Buttonbush was very Important and held 28.4 per cent of all nests. Elder with 19.8 per cent of the nests is third in 1mportance. Myrtle and w1llow with 
8.2 and 6.0 per cent are cons1derably less impartant to the heronry as a whole.

A sumary of the herons' nesting substrate is presented in Table 9. It is interesting that red maple is the most frequent nest site of all specles except the Loulsians Heron. Buttonbush is the second most frequent cholce of all the specles. Loulsiana Herons use elder mare frequently than they use any other bush or tree and they use 1t much more frequently than do the other herons. The two tree specles most frequently used for nesting by each heron specles hold about two-thlrds of the nests of that spec1es, except for the LIttle Blue Heron. The Little Blue Heron shows stronger nest slte preference than do the three other herons and butlds 85 per cent of its nests in maple and buttonbush.

The four heron specles do show differences in thelr nest site. There are three average nest helghts: $5.7,7.2$, or less, and 7.8 feet. These effectively divided the four specles into three groups. The two specles that nest at lower elevations use different trees for nesting. One of them, the Loulslane Eeron, uses elder most frequently and buttonbush next most often and builds many nests in myrtle. The other, the Snowy Egret, uses maple, buttonbush, and elder in that order, and only ccaslonally bullds in.myrtle and wlllow. Thus, although they both nest rather early, these species tend to have reduced Interspec1flc competition because of the differences in nesting substrate. The IIttle Blue Heron builds 1 ts nests hlgher than these two specles do, and the Cattle Egret buflds 1ts nest the hlghest of any of the herons. 
Table 9.--The Species of Trees and Bushes used by Four species of Herons For Nest Bullding at Lake Allce, 1960

\begin{tabular}{lccccc}
\hline & \multicolumn{5}{c}{ Per Cent of Nests 1n Each Type of Tree } \\
\cline { 2 - 6 } & Maple & Buttonbush & Elder & Mytle & W1llow \\
\hline Snowy Egret & 43 & 26 & 18 & 6 & 7 \\
\hline Cattle Egret & 33 & 29 & 19 & 12 & 7 \\
\hline Little Blue Heron & 49 & 36 & 11 & $\ldots$ & 4 \\
\hline Loulslana Heron & 11 & 29 & 39 & 18 & 7 \\
\hline \hline
\end{tabular}


Nest Buslding

In all four species the females bulld the nest with twigs and sticks that are brought to them singly by the males. Male I1ttle Blue Herons and Cattle Bgrets gather their twigs from bushes and trees near the nest 81te. The Little Blue Heron tends to hunt for twigs at all levels in the bushes and trees while the Cattle Egret tends to limit its callectIng to the upper and outer reaches of trees and busbes. In general the Cattle Egret gathers smaller twlgs than do the other specles. Male Snowy Egrets gather all thelr twlgs from the ground or from the water beneath the heronry. Some Snowy Egret nests, especially early ones, are bullt entirely of sticks that have lain beneath the heronry for a year or more and are weathered smooth and often covered wth mud. But females of all specios frequently drop tw1go whlch they are attempting to work Into the nest, and Incomplete nests especlally, and a few complete ones too, may be dismantled and the twigs scattered on the heronry floor. These twigs, including ones broken off by male Little Blue Herons and Cattle Egrets, are found and plaked up by the male snowy Egrets. The Loulsiana Heron pleks up twlgs from the heronry floor in the manner of the Snowy Egret, but 1t also breaks twigs off low bushes and large fallen $11 \mathrm{mbs}$. In all specles there 18 a brief twig passing ceremony which generally Involves elevating certaln feathers, especially those of the crown. All specles but the Cattle Egret spend an average of four to flve days bullding the nest before the first egg is lald, at which time the nost 18 typlcally incomplete. The nest 18 completed during the egg laylng perlod. Cattle Egrets spend an average of between $81 x$ and seven days butlding the nest before they lay tbelr flrst egs, or an average of about two days longer than the other herons. Most Cattle 
Table 10.--Nest1ng Stat1st1cs of Four Species of Herons at Lake Allce

\begin{tabular}{|c|c|c|c|c|}
\hline & $\begin{array}{l}\text { Snowry } \\
\text { Egret }\end{array}$ & $\begin{array}{l}\text { Loulsiana } \\
\text { Heron }\end{array}$ & $\begin{array}{l}\text { L1ttle Blue } \\
\text { Heron }\end{array}$ & $\begin{array}{l}\text { Cattle } \\
\text { Egret }\end{array}$ \\
\hline Days to bulld nest & 4.2 & ( 4 or 5$)$ & 4.6 & 6.6 \\
\hline Days between laylng & 1.9 & 1.7 & 1.7 & 2.0 \\
\hline Number eggs latd & 4.1 & $4 \cdot 3$ & 3.8 & 3.5 \\
\hline Number eggs in clutch & 3.9 & 4.1 & 3.7 & 3.5 \\
\hline $\begin{array}{l}\text { Incubation period } \\
\text { (days) }\end{array}$ & 22.4 & 23.8 & 22.8 & 22.9 \\
\hline $\begin{array}{l}\text { Number eggs day before } \\
\text { hatching }\end{array}$ & 3.8 & 4.1 & 3.7 & 3.5 \\
\hline Number hatching & $3 \cdot 3$ & 3.7 & 3.2 & 3.1 \\
\hline
\end{tabular}


Egret nests are complete when the p1rst egg is laid ar are at least more nearly complete than are nests of the other species.

\section{Egg Laylng and Clutch S1ze}

Most eggs were laid at two-day Intervals, that 1s, the eggs were lald on alternate days. There were no intervals of more than two days. All Cattle Egret eggs were laid at two-day 1ntervals. But occaslonally Snowy Egrets, and even mare frequently, L1ttle Blue Herons and Loulslana Herons (see Table 10) lald eggs on consecutive days. Typlcally there was never mare than one one-day Interval per nest; exceptions tended to be limited to larger clutches.

Snowy Egrets, Louislans Herons, and Little Blue Herons lost an average of 0.2 of an egg per nest between laylng and completion of the clutch. Losses of eggs and the Ir passage through the bottom of Incomplete nests account for most of this loss. However, Cattle Egrets lost no eggo between laylng and completion of the clutch. In splte of these early losses by the other specles, the Cattle Egret still had the smallest clutch, and the differences in clutch size were sufficlently great that there must obvlously be other differences in the life historles of these species.

Although their clutches were the smallest, Cattle Egrets did not have slgnificantly smaller clutches than Little Blue Herons (" $t$ " $=1.18$ ). Nelther did Snowy Egrets have s1gniflcantly smaller clutches than Loulslans Herons $(" t "=1.65)$. All other differences in clutch size were slgaificant, for example, the differences between Little Blue Heron and Snowy Egret clutches had a " $t$ " of 3.46 . 
Although no Intentlonal experiments were performed, the dally removal of eggs from same nests by predatars and other egg losses lead to the conclusion that all four of these herons are indeterminate lavers, but that the maximal number of eggs they can lay serially is about double the average clutch size for the specles.

\section{Incubat1on}

The incubation perlods of these herons are quite sirilar (see Table 10). The Snowy Egret has the shortest average incubation perlod, the Little Blue Heron and Cattle Egret require an average of about half a day longer. The Loulslana Heron requires one and a half more days for Incubation than did the Snowy Egret, and a day more than do the two specles with the Intermediate incubation perlod. Because Loulsiana Herons have the largest clutches, nest first when temperatures are st1ll low, and do less late nesting than the other species, It could be reasoned that their longer Incubation period is a result of the birds' Inabil1ty to keep mare eggs durling cooler weather as warm as the other specles do less eggs in warmer weather. However, there is no evidence to substantiate these 1deas and no correlations between early and late, or small and large clutches could be made.

In all four specles both sexes incubate. The adults stand over the eggs and shade them during mid-day in late spring and sumer. Cattle Egrets shade their eggs mare than the other specles and in this case the difference is doubtless related to the later nesting of the Cattle Egrets. 


\section{Hatching and the Young}

Young herons of all four specles aften oall inside the egg befare they p1p. The eggs are usually pipped one day or slightly less, rarely two days, before the young emerge. The edults (of all species) remove the empty shells after each young hatches, and drop the shells over the edge of the nests. About the time the P1rst egg 1 plpped the adults also remove any cracked or empty eggs oven though they may have incubated them for the full perlod.

On the first day of hatching Loulslana Heron broods average 2.2 young; most of their broods are complete by the third or fourth day of hatching. Snowy Egret and L1ttle Blue Beron broods average 1.5 and 2.6 young respectively on the flrst day of hatching, and most of their broods are complete by the third or fourth day of hatching. Cattle Egret broods average 1.1 youmg on the f1rst day of hatching and most of their broods are not complete until the flfth day of hatching.

The average number of young hatching per nest is closely related to the number of eggs per clutch (see Table 10). Most Snowy Egret, L1ttle Blue Heron, and Loulslana Heron hatchlings are brooded almost continuously during their first few days of nest life, but when they are able to hold their heads upright and strike at objects, the two parents simultaneously vacate the nest. Cattle Egrets spend considerable time shoding the young, but individual young Cattle Egrets probably do not recelve as much parental brooding and shading as do nestlings of the other herons. Cattle Egrets hatch over such a long perlod of time that both parents are off gathering food for the older nestling whlle the youngest are st1ll so undeveloped that thoy would be continually attended if they were by themselves. The newly hatched young probably passively 
recelve many of the benef1ts of brooding from their older siblinge. Also, since Cattle Egrets nest substantlally later than the other specles do, there 18 conslderably less danger that the young might become chllied during the day.

The young dry off shortly after hatchlng. They are relatively helpless and remaln in the nest for some time and have down growing only on the future pterylae. At first they are extremely weak and seldom peep or raise thelr heads but after two or three days they peep mare and hold up thelr heads for relatively long perlods. Although at first they pick food up from the nest floor they soon take it directly from the parent's bIIl and shartly reach dow into the parent's gullet for the food.

There is no evidence that any of these birds raise two broods in one season elthough the over-all breeding season is sufficiently long for this to be done.

\section{Mortal1ty of Eggs and Young}

Even before the first egg is laid varlous factors which increase mortallty begin to operate. Wind often blows down nests that are just being started, In most cases this is probably due at least in part to the adults trylng to build the nest at an impossible site. Other herons may try remorling twigs from a temporarlly unprotected nest, and if the nest is just started it usually falls to the ground. Even sturdy nests can seldom survive the removal of more than two or three tulgs. These delays in nest completion often result in the bird's laying the first egg befare the nest is complete enough to hold the egg. 
The Cattle Egret spends conslderably mare t1me bullding 1 ts nests than do the other herons, and Its nests are much more complete before they start laylng. The cattle Egret loses prectically no eggs between laylng and Incubation whlle the other specles lose between 3.9 and 5.4 per cent of their eggs (see Table 11). Not only are Cattle Egret nests mare complete but the adults are more attentive, and incubation starts with the laying of the second egg.

Sometimes the birds never succeed in their efforts to bulld a nest. One nest that never reached completion was started on Apr11 20, 1960; It was there the 2lst, but completely gane the next day; on Apr11 26 a nest was started at the same place, the next day it was a large nest, but a day later only a few twlgs remalned, and on Apr1l 30 there was no evidence of the nest; on May 31 was started, but on May 5 it was gone; on May 7 it was started again, and on May 9 it was gone agaln. In 19 days th1s nest was started four t1mes, and each time it lasted for at least two days, and It disappeared four t1mes. Th1s part1cular nestIng effort was the work of a pair of Little Blue Herons. There was no activity at the site for the next month and a half, but in late June a pair of Cattle Egrets built a nest at the same site. They laid and hatched flve eggs with no apparent difflculty.

Grackles or other predatars may find a heron's nest and remove the eggs as regularly as they are lald. One Snowy Bgret nest that was regularly robbed never did produce young. Thls particular nest was started on Apr11 5, 1960. The f1rst egs was found on the 11th and on the 13 th there were two eggs. On the 14th there was only one egg, a new one, and the next day there were none; on Apr11 17th the fourth egg was laid, and the next day It was gone and the nest again empty; on April 19 
one egg was added, but it was removed by the next day. Then the clutch was completed; eggs belng laid on the 2lst, $23 \mathrm{rd}$, and 5th of Apr 1 , and Incubation proceeded for nine days. On the 5th of June egg number two disappeared. On the 7 th number one was gone, and on the 8 th number three was gone. On the gth the nest was reduced to a few twlgs scattered beneath the tree. Most of these eggshells were recovered. They had been opened and eaten by birds, apparently Boat-talled Grackles (Cass1d1x mextcanus).

Purple Gallinules (Porphyrula martintca) also take eggs fram nests. Young Purple Gellinules feed on eggs brought to them by the adult b1rds. A few eggs that had been crushed Imwardy unt1l the outer shell was a cluster of tiny fragments held together by the membrane were found at widely scattered locations. They had apparently been taken and eaten by Rat Snakes (Elaphe obsoleta), the only arbareal snake seen in the heronry.

Floh crows (Corvus ossirregus) are common on the University campus adjolning Lake Allce. They often perched in trees around the lake, and nearly every day of the 1960 breeding seeson they were seen flylng over the heronry. It 18 interesting that these $118 \mathrm{~h}$ crows were never seen in the heronry proper, and there was no martallty elther of egge or young that could be attributed to these blrds. There was no evldence of any manalian predation. In fact there was never any evidence of mammals other than mice having been in the heronry. Raccoons (Procyon lotar) and other potent1al mamalian predators are doubtless incampatible with the American all1gator (All1gator mississiplens18) whlch is aumerous at Lake Allce. 
Alligators from one foot to $81 x$ feet long and occaslonally larger individuals scavenge in the heronry. These animals promptly eat dead nestlings, regurgltated $11 \mathrm{sh}$ and frogs and anything else remotely edible that falls to the heronry floor. In performing this scavenger servlce they keep the heronry largely free of the blalogical wastes that would have attracted Flsh Crows, raccoons, or other potentlal predatars.

A great many nests are blown down, destroyed, robbed, ar deserted during construction, eg8-laying and early incubation. Probably well in excess of half of the nests started never reach the point of containing a full clutch. Once the clutch 18 complete and Incubation gets under way, the esgs are relatively safe. But even then predators manage to get a few nests, and when they do they generally take all the eggs, often removing them one at a time over a perlod of several days.

From the day before hatching starts through hatching there is a martality of from 10 to 15 per cent (see Table 11). There 1s same 1088 of young to predators at this time. The adults are restless and they accldentally crush an occaslonal egg or young whlle moving around on the nest. Unaccountably the snowy Egret nests suffered the highest hatching martality. The over-all martallty from egg laying through hatchlng ranged from a low of 12.6 per cent for the Cattle Bgret through a hlgh of 19.3 per cent for the Snowy Egret. The Cattle Egret, Ilttie Blue Heron, and Loulsiana Heron had simllar martalitles at hatching but the Cattle Egret's lack of 1083 in the egg laylng perlod did much to suppress 1 ts over-all mortal1ty.

Cattle Egrets lose practically no nestlings durlag the first two woeks after hatchlng. The cattle Egret mortal1ty of 5.7 per cent of 1ts nestlings represents a loss of about one young from every f1ve nests. 
Snowy Egrets, Little Blue Herons and Loulsians Herons bave a nestling martality of from 25.4 to 32.6 per cent during the first two weeks. Most of this loss 18 due to starration. The last sibling to hatch in practically all the larger clutches of these three specles is usually so far behind his older siblings that he seldom gets enough food to survive for mare than a few days. Only occaslonally did mare than one young starve in a nest. This $108 s$ averages about ane young per nest, however young were seldom starved In broods as amall as two. The Snowy Egret had the highest nestling martallty, whlle the Little Blue Heron and Loulslana Heron had very similar mortalities.

The over-all martality of eggs and young from nests in which young eventually hatch varles from a remarkably low 17.5 per cent for the Cattle Egret to a surprisingly hlgh 45.6 per cent for just the perlod from egs laying through the first two weeks of nest I1fe (Table II). There is another perlod of rather high mortallty when the young firgt leave the nest and start climbing about in the trees. Young often fall to the ground. At Lake Allce the vegetation is sufficlently bushy for these young usually to climb back to their nests, but at other places where herons nest in large ature trees, the inability of young that fall from nests to get bock 1nto the trees is an Important factor in martality. At Lake Allce a few young are caught by alligators before they get back in their tree, and sprunt and Chamberlain (1949) repart recovering bands from young Lousiana and Little Blue Herons from an alligator stamach. Strong winds and heavy rains result in losses; young are knocked from trees and are hung in vegetation oi have their feathers matted viti mud and pounded into the mud. 
Table 11.--Mortal1ty of Eggs and Nestlings of Four Herons, Lake Alice, 1960

\begin{tabular}{lcccc}
\hline & \multicolumn{3}{c}{ Martal1ty in Per Cent } \\
\cline { 2 - 5 } & $\begin{array}{c}\text { Snowy } \\
\text { Egret }\end{array}$ & $\begin{array}{c}\text { Cattle } \\
\text { Egret }\end{array}$ & $\begin{array}{c}\text { L1ttle Blue } \\
\text { Heron }\end{array}$ & $\begin{array}{c}\text { Loulsiana } \\
\text { Heron }\end{array}$ \\
\hline $\begin{array}{l}\text { Laying to day before } \\
\text { hatching }\end{array}$ & 5.4 & 0.0 & 3.9 & 3.9 \\
$\begin{array}{l}\text { Day before through } \\
\text { hatching }\end{array}$ & 14.7 & 12.6 & 12.1 & 10.5 \\
$\begin{array}{l}\text { Laylng through } \\
\text { hatchling }\end{array}$ & 19.3 & 12.6 & 15.6 & 14.0 \\
$\begin{array}{l}\text { Hatching through } \\
\text { two weeks }\end{array}$ & 32.6 & 5.7 & 26.2 & 25.4 \\
$\begin{array}{l}\text { Over-all martal1ty } \\
\text { from laying through } \\
\text { two weeks }\end{array}$ & 45.6 & 17.5 & 37.6 & 35.8 \\
\hline
\end{tabular}


Cattle Egret broods averaged 2.9 at the end of two weeks of nest 11fe. Loulslana Herons averaged 2.8 young, Snowy Egrets averaged 2.6, and Ittle Blue Herons averaged 2.4. Although these Cattle Egret broods were not slgnificantly larger than Louislana Heron broods ("t" $=0.97$ ), the Loulstana Heron clutches contained slgniflcantly mare eggs than Cattle Egret clutches (" $t "=4.29$ ). The Cattie Egret has such a low nesting martality that in spite of its laying fewer egss than the three other herons, it produces more young. 


\section{COMPARISON OF THES FYEDDIN HABITS OF THHE SFECISS}

The eating of different foods, or at least gathering their food from different areas would be the final proof that two or mare herons are occupylng different niches, that their ecologles are different.

\section{Feeding Behavior of Adults}

One occaslonally finds dense little groups of Snowy Egrets and Little Blue Herans, and scmetlmes Loulsiana Herons, clustered around a roadside culvert, alang a small meadow canal, or on a pond. But it is unusual to flnd these three specles gathered together and feeding on the same thing. Indeed, it is not usual to find concentrations of Individuals of the same species gathered together in t1ght groups and feeding on the same prey. I once saw a group of about elght Loulslana herons and twlce that many Snowy Egrets feeding together near Cedar Key. These birds were running around chasing floh and making otrikes in all drections in a small pond, about 50 feet long by 10 feet wide, in which an umusually low tide had concentrated 11 sh from an area of several acres. All examples of compact mixed feedings are not so clearly brought about by such an unusual and abundant supply of food, but they are usually related to sudden fllling of arees, or thelr rapld drylng. Such concentrations do not occur frequently but they do occur and their prompt use certalnly reflects the adaptiveness of the herons. 
In their day to day feeding the four herons seem to feed consistently in slightly different habitats. They are of course usually Iinfted to areas where the water is not too doep (1ess than elght Inches) and to areas where there 18 not too much vegetation. However, adult herons sametimes feed by fyling low over the water, or hovering, and reachlog down Into the wator to grasp prey in the b111, and they sometimes feed from floating objects. When they feed in these ways they are not restricted by depth; but these are not typlcal feeding techntques and are probably employed by the birds to enable them to take advantage of some unusual bounty. Snowy Egrets spend most of their time feeding in water a few inches deep, as do Little Blue Herono. Loulslans Berons feed in deeper water, and anly rarely do Cattle Egrets feed in the water. In splte of the Breat amount of overlap and the simllarlty of the adults' behavior, there st1ll appear to be olenif1cant differences.

Ilttle Blue Berans often feed in somewhat more heavily vegetated. arees, in more marsh-like places than do snowy Egrets, which do much feeding in open areas of shallow water, although they too are often seen standing at the open water edge of emergent vegetation around ponds or small lakes. Snowy Egrets Indulge more in Act1ve Pursult, running around in shallow water striking at $\mathrm{Plsb}$, wile the L1ttle Blue Heron Is more of a Stand and Walt, and Wade or Walk Slowly feeder. These differences mlght in part be due to differences in the types of areas in whlch they hunt. Active prrsult, whlle successful in shollow, open water would be considerably less effective in deeper water or in denser vegetation. 
The Loulsiana Heron typlcally feeds in deeper water than does the Snowy Egret or Little Blue Heron. It often wades in water to a depth of its belly or leg feathers. The Louislana ferons also feed along the edges of canals ar other banks where the water drops off rapldzy, and from Iloating ar submerged vegetation in deeper water. Although In the Galnesville area it feeds primarlly by stealth, It sometimes chases Plsh about In shallow water and takes prey from deep water by "hover1ng."

Durling the breeding season the Cattle Egret feeds almost exclusively in company with large animals, usually cattle. Its most impartant feeding areas are around the edge of Payne's Pralrie and in the nelghborlng pasture lands. The Cattle Egret walks along beside the head ar flank of a grazlng cow and catches prey the cow flushes. Although cows frequently wander into the water, the Cattle Egret does most of $1 t_{B}$ feeding in drier pastures and quickly abandons the cows if they wander Into water deeper than two ar three 1nches. Snowy Egrets sometimes assoclate w1th cows around Gaineav1lle, but this is rather unusual bebavlor for them. However, Snowy Egrets and L1ttle Blue Herons occaslonally feed away from water and sometimes feed in hlgh pastures quite far from water. In these places they feed by walking slowly through the grass catchlng prey that flushes at their approach, or, especlally the Ilttle Blue Heron, by the mare stealthy Wade or Walk slowly technique. I have not seen Loulslana Herons feeding in these areas.

Although observations of foeding adults do reveal differences between the specles, these dfferences are nolther sufflclently consplcuous, nar sufficlently great to be regarded as any mare than 
Indicative that the birds, exclusive of the cattle Egret, are doing different things.

\section{Food Hab1te of the Young}

The food of the young of the four herons, as determined by the analysis of 50 regurgitated pellets from each species 18 grouped Into major categarles and presented in Table 12. There are some conspicuous differences between specles: the IIttle Blue Beron eats mostly amphiblans, the Loulsiana Heron and the Snowy Egret eat mostly floh, and the Cattle Egret eats primarlly invertebrates. Differences in the degree of diversification of food are also consplcuous: the Little Blue Heron has a widely diversifled diet and eats fairly large quantities of flsh and Invertebrates in addition to the amphiblans. The Loulalana Heron and Snowy Egret have much less varled diets and practically limit themselves to flsh. However, the Cattle Egret eats mostly arthopteran 1nsects but does eat a great many amphiblans and a few reptiles in addition to the invertebrates.

Snowy Egrets eat primarlly Fish and their pellets average 20.50 flsh. The mosquitorish is the most important apecies with an average frequency of 9.0 per pellet and the least k1ll1flsh is the second most frequently taken and averages 4.5 per pellet. The redein plckerel was taken flve times more often by Snowy Borets than by IIttle Blue Berons and was not recarded from the Loulslana Heron. Mosquitofish and least killifish occur in most any water offering them shelter, but they are most commonly found in very shallow water, and the redfin plakerel is practically limited to such shallow water. The bigh frequency and Impartance of these three f1sh in the Snowy Egret diet and the frequency 
Table 12.-Analysis of Contents of 50 Pellets Regurgitated By the Young of Each of Four Spec1es

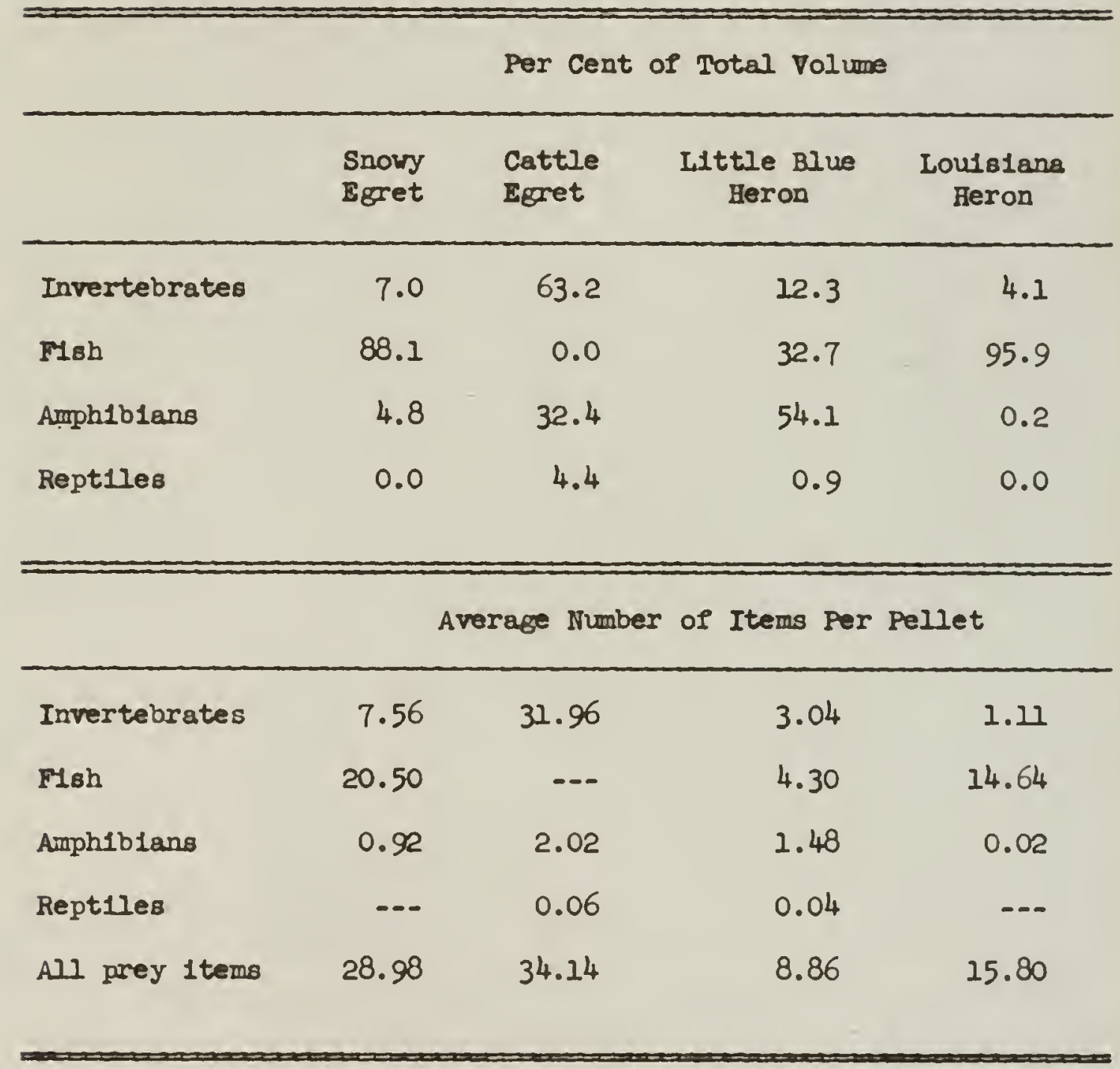


of very small tadpoles indicates that most of the ir food is taken in shallow water. The occaslonal appearance of sunflib or grasshoppers Indicates that the birds occaslonally feed in deeper or in drier areas. Cattle Egret pellets Include an average of 32 insects. The average number of Individual prey 1tems 1813.6 short-horned Grasshoppers per pellet, 10.5 crlckets, 5.6 long-harned crasshoppers, 1.8 splders, 1.4 cricket frogs, and 0.5 leopard frogs. Young Cattle Egrets regurgltate no f1sh, tadpoles, aquatic invertebrates, or aquat1c frogs. The food apparently all comes from upland sltuations, from open grasslands where meadow frogs are found, and these are the areas where the adult Cattle Egrets feed, though they do sometimes feed in wotlands and occaslonally in water several inches deep. However, in addition to the 50 pellets reported on here, several hundred were checked in the fleld and 50 more from Lake Allce, and 50 mare from each of three other localities were carefully anolyzed and no purely aquatic prey with the quostionable possibility of a few small beetles was found.

Though L1ttle Blue Herons eat nearly three times as many f1sh as amphlblans, the amphiblans make up the largest bulk of their diet. They do not eat the same kinds of frogs that cattle Egrets eat. While Cattle Egret pellets average 1.4 crlcket frogs and 0.5 leopard frogs, LIttle Blue Beron pellets average less than 0.1 orlcket frogs and only 0.1 leopard frogs per pellet. Ilttle Blue Herons eat such aquatic amphiblan forms as large rantd tadpoles and bullfrogs, 0.5 and 0.1 per pellet. Flsh are 1mportant and golden topminnows, 1.0 per pellet, contribute by far the bulk of the volume attributed to f1sh. Banded topminnows, 0.2 per pellet, are the second most Important 11sh. Relatively few 
mosquitofish, 0.6 per pellet, are taken in comparison to the number of least k1ll1f1sh, 2.1 per pellet, and other $118 \mathrm{sh}$ taken. The ways in whlch the Ilttle Blue Heron's Ilsh det differs from that of the Snowy Egret Indicates that it feeds in deeper water than does the snowy Egret. Bven compared to the highly plsclvorous Snowy Egret, the Loulslana Beron stands out clearly as a flsh specialist. The only Important deviation from a stralght P1sh diet 1s the Inclusion of 0.6 dragon-flles per pellet. All four of these herans eat dragon-flles and the Incldence of dragon-flles in the diet la greater when the Incldance of $118 \mathrm{~b}$ is preater. The flagflish was both the most numerous, 4.1 per pellet, and most impartant, 36.8 per cent by volume, prey taken by Loulsiana Berons. It is a shallow water flsh but is found less frequently than are mosquitoflsh and least killif1sh in water from two Inches to one-fourth Inch deep. Flagflsh are mare readly found in water several inches deep. These last two specles are the next most often taken $118 \mathrm{sh}, 4.1$ and 2.9 per pellet, and the mosquitorish contributed only about a third as much to the over-all det as did the flag11sh. Although numbering only 1.6 per pellet, the second most impartant flsh was the golden topminnow, anotber f1sh that probably ranges in deeper water than do mosquitoflsh and least k1ll1f1sh. Loulslans Berons also eat a fow each of several other specles of flsh typleally found in deeper water. The complete absence of tadpales and near absence of frogs Indicate that the adults do not usually feed in areas where they would be apt to flnd amphlblans, that 18, they probably do not normally feed in very shallow water ar on tempararily flooded flats. 
The flagrish makes up 36.8 per cent of the food of the Loulsiana Heron, and the mosquitofish makes up 36.1 per cent of the Snowy Egret's food. The golden topminnow is second most impartant to the Loulsiana Heron, but the Flagflish is second most Important to the Snowy Egret. The mosquitoflsh, first for the Snowy Egret, is third in impartance to the Loutslana Heron, and the redfin p1akerel, whlch is not recorded from Louls lana Heron pellets, 18 the Snowy Egret's third most impartant prey. There appears to be good basis here for considering these two strongly piscivarous birds to be flshing in different niches. The great number of mosquitofish and least k1111fish (456 and 224) and several redfin pickerel eaten by the Snowy Egret, argue for a very shallow feeding area. The reduced abundance of mosquitofish and least k1111fish (205 and 143) and Increased abundance ind importance of flagfloh and golden topminnows in the Loulslans Heron det Indicates that this specles feeds in deeper water. The inclusion of even a few warmouth, bluegill (Lepomis macrochirus), and black crappie (Pomoxis nigromaculatus) in the diet of the Loulsians geron and their complete exclusion from the diet of the Snowy Egret also indleates that the Loulslana Eeron is feeding in deeper water. Therefare the two flshfeeding birds can be regarded as utllizing mutually exclusive areas; one deep water and the other shallow.

The LIttle Blue Beron eats st11l different fish and although the Ilsh It takes Indicates that It feeds in deeper water than does the Snowy Egret, it eats practically no flaffish and therefare does not appear to be feeding in the same areas as the Loutslane Heron. The Ilttle Blue eats a large number of topminnows which are extremely important in Its diet. 
These four herons show rather distinct differences in their feedIng patterns: Snowy Egrets Plish in shallow water, Loulslana Herons flsh in deeper water, LIttle Blue Herons feed on amphibians and $\mathrm{flsh}$ they catch in water of Intermedlate depths, and Cattle Egrets catch arthopteran Insects and amphiblans in relatively dry pastures.

The valume of the pellets regurgitated by the four herons shows considerable varlation in spite of their apparent simllarity in size. Little Blue Beron pellets average $10.15 \mathrm{ml}$., Loulsians Beron $7.06 \mathrm{ml}$, Snowy Egret $9.41 \mathrm{ml}$, and cattle Egret $4.82 \mathrm{ml}$. There are at least four factors contributing to these differences: (1) there is a real difference in the size of the pellets, whlch 18 due in part at least to (2) the large s1ze of some prey, for example, Little Blue Herons ate four bullfrogs whlch averaged $21.5 \mathrm{ml}$. Certain prey items (3) such as the few dragon-flles in Loulsiane Heron pellets and the mainly intact insects in Cattle Egret pellets may occupy an excessive amount of space for their volume, and (4) small froments and disarticulated Insect appendages vere excluded from the pellet analysis and as a result a substantial partion of every Cattle Egret pellet was discarded befare its valume was measured.

The average number of food 1toms per pellet varies markedly. Little Blue Heron pellets contaln an average of 8.86 indivlduals, Loulstans Heron 15.80, Snowy Egret 28.98, and Cattie Egret 34.14. The number of prey 1 tems and the valume of the pellets vere not correlated, but number of prey items and type of prey are correlated. Average size of the Invertebrates eaten by Snowy Earets and Cattle Egrets ( 0.09 and $0.10 \mathrm{ml}$. ) 1s small because they consist mostly of short-and long-horned 
grasshoppers and crickets. Little Blue Herons eat a few crayfish and the average invertebrate 18 flve t1mes larger $(0.41 \mathrm{ml}$ ). Ilttle Blue Heronseat larger Plsh (average $0.78 \mathrm{ml}$ ) than do elther Loulsiana Herons or Snowy Egrets $(0.46$ and $0.40 \mathrm{ml}$.$) , and this 1 \mathrm{~s}$ due in part to the Iittle Blue Heron's eating several flsh specles of large size: topminnows, warmouth, banded sunfish, redfin pickerel, and others. The Loulsians Heron's and the Snowy saret's flsh prey include specles of small s1ze. Even the average size of flah of the same specles eaten by these three birds differs. For example, the average valume of the golden topminnows 1s: Ilttle Blue Heron, $1.50 \mathrm{ml}$; Loulsiana Heron, $0.98 \mathrm{ml}$; and Snowy Egret, $0.86 \mathrm{ml}$, and the average size of the least kllliflsh is Ifttle Blue Heron $0.15 \mathrm{ml}$, LoulsLans Heron 0.11 , and Snowy Egret $0.07 \mathrm{ml}$.

\section{Feeding Behavlor as Related to Food}

The food habits of these birds agrees closely with their feeding behavlor. The Snowy Egret feeds mostly in shallow water and most of Its food is flsh, those specles found most abundantly in shallow water. They occasionally feed in open prasslands away from water and sometimes feed with cattie, and a few of thelr pellets are composed entirely of grashoppers and crickets. The Cattle Bgret seldom feeds in wetlands except when a cow belng used as a Plusher or beater wanders into the water. The Cattle Egret feeds mostly in relatively dry pastures and seldom feeds independent of cattle. The Cattle Egrets eat mostly Erasshoppers and crlckets and although they eat many crloket frogs and leopard frogs, these two farms frequent grasslands and are not strictly 
aquatic frogs. No aquatic forms are found in the food of Cattle Egrets. The Little Blue Heron is a strongly aquatic bird and although 1t occaslonally feeds in pastures ar around drled wood ponds, it mostly feeds in water a few inches deep, but not typlcally as deep as the Loulslana Heron feeds. Their pellets contaln aquatic amphlblans and 11sh. The Loulslana Heron 1s the most completely plsclvarous of these birds, and the adults are never seen feeding away fram the water. Loulsiana Berons consistently feed in deeper water than do elther Snowy Egrets or L1ttle Blue Herons; here they catch only f1sh, primarily flagfish and an occasional dragon-fly. 


\section{CONCLUSIONS}

In the course of this study information on the breeding and feeding biology of the Snowy Egret, Cattle Egret, Little Blue Heron, and Loulsiana Heron was gathered. Th1s information on breeding was presented and discussed in detall earlier in this paper. The comparative feeding behavior and food hablts of the four herons were described and discussed also. With this information it is possible to make some tentative generalizations regarding the soclal relationships among the four herons and to augment what is known of their breeding ecology.

\section{Nest site}

Although there is ilttle contact among the four specles of herons outside the breeding season, there is some contact among them during the breeding season. In establishing and defending their territories, males of all four specles repel all herons of their own or of any other specles that approach too closely. Herons establishlag their territorles later move in as close as possible to the holdings of the early arrivals. Males arriving late do not appear to select territories near males of their own species in preference to those of other specles, but take up territories near those of any already-established individual, regardless of species. Soclal nesting in these herons thus tends to be with any heron specles rather than species-restricted. In addition to th1s soclal nesting, the only evident relationshlps between these four 
specles are competitive in nature. The nesting habltats of these four herons at Lake Alice are slightly different. Snowy Egrets and Loulslana Herons nest early and at the same helght, but for the most part they select different trees and bushes. The Loulsians Heron nests in elder and other bushes in open areas whereas the Snowy Egret nests in dense vegetation such as the maples which grow in the middle of the 1sland. Little Blue Herons and Cattle Bgrets nest in the same trees as do the Snowy Egrets, but they nest higher. These differences in nest helghts result in a vertical stratification in the dense, tall vegetation with Cattle Egrets nesting above Little Blue Herons wh1ch in turn nest above the Snowy Egrets. There is also a horizontal stratiflcation. The Loulsiana Heron nests around the edge of the heronry and in other open areas. Thls complex stratification is not due to differences in the herons' preferences, and is therefore not always manifested.

In 1960 , early Little Blue Heron nests averaged 6.4 feet above the ground while those completed after April 28 averaged 8.5 feet. This difference $1 \mathrm{~s}$ slgalficant $(" t "=6.63)$, and the 1ncreased helght of late nosts thus obtains within all species as well as between species.

\section{Nesting Mater1als}

The heronry must not only provide these herons with a potential territory, but must also provide them with nest bullding materials which are gathered outslde the territory. These herons all make their nests out of small sticks and twigs, collected in or adjacent to the heronry. Snowy Egrets plck twlgs up off the ground. Loulsians Herons usually do likewlse, but sometimes break twlgs off dead branches and limbs near or on the ground. Cattle Egrets and Little BIve Herons break IIVIng and 
dead twigs off trees and bushes. Cattle Egrets tend to limit their twig gathering to the upper and outer reaches of the trees, where they take smaller twlgs. Late in the 1959 nesting sesson, Cattle Egrets took nest material from trees around the edge of Lake Allce; this was the flrst year that any of the herons gathered nesting material away from the heronry. In 1960, Cattle Egrets again took tw1gs from the lakeshore, but started dolng so in the middle of the nesting season, much earlier than in 1959. By the end of the 1960 season they were bringing twlgs back from more than half a mile away. These differences In the sources of buslding twigs tended to reduce, though by no means eliminate, competition among specles for thls materlal. That these differences may not be characterlstic of the specles everywhere is suggested by Meanley's (1955) observation that in Arkansas, Little Blue Herons gathered nesting material fram the water beneath the heronry that he studied.

The herons do not feed in the heronry and there appears to be little in this aree besides nest sites and nest material which might be in shart supply and over which interspeciflc competition mlght arise. Other benefits the birds derlve from the heronry, lncluding association with one another, probable freedom from predation, and other benef1ts, are much mare subtle, and do not readily lend themoelves to quantstative description.

\section{The Island Location}

One feature the Lake Allce heronry has in common with most other Forida heronrles, is 1ts location on an 1sland. Florida heronries not located on 1slands are usually found in trees growling in rather deep 
water. Furthermore, fresh water heronries in Forida tend to be located where there are alligators. Two salt water heronrles near Cedar Key, Forida, are on 1slands whlch also support large populations of cottonmoutho (Agkistrodon plsc1vorus, Wharton, 1958). Th1s almost universal "1sland" location of heronrles may help free them from mamalian predstors. Raccoons (Procyon lotor) were speciflcally Implicated in the destruction and abandonment of a Roseate Spoonb111 (Aja1a aja1a) colony in Florida Bay (Allen, 1942). The absence of raccoons and other manmals from Flarlda heronrles suggests that the heronrles are not accessible to them, and is probably a critlcal factor In the permanence of the nesting areas. Other requirements, such as nest sites and nesting materials, are certainly mare widely avallable to herons than is freedom from mammalian predation.

\section{Feeding Niches}

The four herons occupy different feeding nlches. That of the Cattle Egret is clearly unlque. Feoding hablts of the other three specles superflcially appear essentlally 1dent1cal, but mare detalled observations of adult feeding behavior, and analysis of pellets regurgitated by young birds reveal that these four specles diverge in feeding preference and behavior.

The Cattle Egret feods exclusivaly on terrestrlal food, usually in assoclation with cattle or other grazing antmals, although sometimes It forages alone. It captures 1nsects, primarily grasshoppers and crlckets, and upland frogs.

The three other herons feed mostly on aquatic prey. The snowy Egret usually forages in shallow water where it captures small f1sh--primarily 
mosquitoflsh--and a few tadpoles and insects. The Little Blue Heron feeds in slightly deeper water and takes mostly amphlblans, largo rantd tadpoles and frogs, and a large valume of $\mathrm{flsh}$, primarlly topminnows. The Little Blue Heron takes larger flsh than any of the other herons. The Loulsiana Heron feeds in deeper water than even the Little Blue Heron, taking medium to small-8lzed flsh, primarlly Nagfish. It is the most confirmedly plscivarous heron studied.

Apparently feeding areas must be sufflclently close to the breeding place that the birds can make several round trips between the two places during the rearing periods. They must provide an adequate concentration of sultable prey for the b1rds. However, the feeding ecology of the heronry has not been adequately studled.

\section{Establ1shment and Abandonment of Heronries}

To be selected as a breeding place by herons, a site must, besides beling reasonably close to feeding areas, also offer suttable space for territories and supports for nests, must have an adequate supply of nesting materials, and must be free from excessive predation, which apparently means complete or nearly complete absence of marmalian predators. Places offering approprlate territarial and nest sites and nesting material, near sultable feeding areas appear to be plentiful, but the number of such places that are also free of predatory mamals 18 probably smaller. Floating islands, small mangrove 1slets, 1slands w1th large cottonmouth populations, and spoil banks in lakes and bays, have already been mentioned as areas supporting heronries. In recent years heronries have been established in cypress trees in Florida phosphate settling ponds. These areas have one feature in common, 
besides their aquatic location: they do not support raccoon populatlons, and are difficult if not impossible of access to raccoons.

In some cases, heronries have been abancioned simply because of human disturbance. As an extreme example, all the nest trees of a small heronry near Brooksville, Florlda, were removed durling 1960, and there remsins only a treeless, bushless pond. But berons sometimes leave nesting areas for no apparent reason, as they abandoned BIvin's Arm near Galnesville in 1948. Except for those caused by human interference, no cases of heronry abandonment have been sat1sfactorily explained.

The herons may be an important factor in alterlag their ow breedIng habltat and making it unfit. Even a medium-s1zed colony of birds such as that breeding at Lake Allce is quite hard on the nesting vegetat1on. The bushes and trees that best sat1sfy the berons' requirements are typically those growling in marginal situations. The welght of roosting bleds breaks off $11 \mathrm{mbs}$. Tw/g bunting males serlously prune the trees and apparently break off every trig avallable in the beronry. Cattle Egrets had to leave the heronry to hunt twigs during the latter part of 1959 and 1960. The total Impact of the birds of the 1r nest1ng substrate is great, and when the extent of the sultable hab1tat is small as it is at Lake Alice, the birds can probably effectively destroy the habltat. In a large area such as Blrd Island, in Orange Lake, tbe effect would be relatively less than at Lake Allce and the b1rds would probably not be able to do much permanent damage.

Herons often establish breeding areas in vegetation k1lled by artiflcial flooding, as at Lake Allce. Such areas can be expected to provide sultable nesting places for only a few years, unless the dead 
trees are supplemented by the growth of new aquatic trees and bushes. At Lake Allce new growth has been 1nadequate, and each year since 1957 there has been less nesting substrate. Since 1959 the White Iols have falled to nest at Lake Allce, and the vegetation has continued to decline, and if the present trend continues the place w1ll probably be deserted by the herons w1h1n a few years.

Thus, there are several factors other than human interference that may cause herons to abandon an established breeding area. For example, the fallure for any reason of the heronry trees and bushes to frow and replace themselves would decrease the number of territorial and nest sites, and the amount of available nesting materlal. However, as was sald above, Cattle Egrets at Lake Allce gather some of their nesting material away from the heronry. The heroury might become accessible to manmalian predators, as a result of lowered water levels or in any of several other ways. Although there 1s, as yet, no evidence for 1t, the heron ectoparasite population concelvably might, over a period of years, increase to a density that would cause the birds to leave. The avallable feeding areas might be so altered, for example by changed water levels, as to be no longer suftable. The final explanation of why herons abandan a long used breeding place will probably lnvalve at least one such subtle or gradual change. 


\section{LIIERATURE CITED}

Allen, Robert P.

1942 The Roseate Spoonbill. Nat. Aud. Soc., Rep. No. 2, $142 \mathrm{pp}$.

Allen, Robert P., and Frederick P. Mangels

1940 Studies of the nesting behavior of the Black-crowned Night Heron. Proc. Linn. Soc. New York, Nos. 50-51: 1-28.

Anonymous

1961 Climatological Data. Florida. Annuwl Surmary 1960. U.S. Department Commerce, Weather Bureau 64(13): 197-208.

Austin, Oliver L., and Nagahisa Kuroda

1953 The birds of Japan/their status and distribution. Burl.

Mus. Comp. Zool. 109(4): 276-c37.

Baynard, Oscar E.

1912 Food of herons and 1bises. Wilson Bull. 24(4): 167-169.

Bent, Arthur C.

1926 Ilfe histories of North American marsh birds. U.S. Nat. Mus. Bull. 135: 1-491.

Cooke, C. Wythe

1945 Geology of Florida. Florida Geol. Survey, Tallahassee. Geol. Bull. 29, $339 \mathrm{pp}$.

Davis, David E.

1955 Breeding blolocy of birds, pp. 264-308. In Recent studies in avian biology. Am. Ornithologists' UnIon, Univ. Illinois Press, Urbana.

Dawson, Willian L.

1915 The breeding of the Snowy Egret in California. Condor 17 (2) : $97-98$.

Dickinson, J. C., Jr.

1940 Luke Nlice. Unpublished manuscript, $92 \mathrm{pp}$.

Dickinson, J. C., Jr.

1946 Census of nesting birds in the Bivin's Arm sanctuary.

Florlda Naturalist $20(1): 9-10$.

Dickinson, J. C., Jr.

1947 Unusual feeding habits of certain herons. Auk 64(2): 306-307. 
Genier, Albert $F$.

1960 A new heronry in narthwest Tennessee. The M1grant 31(3): $48-49$.

Bowell, Arthur $\mathrm{H}$.

1932 Morlda blrd l1fe. Coward-MoCann, Inc., New York. 579 pp.

Lack, Darld

1954 The natural regulation of animal numbers. Coxfard Univ. Press, London. $343 \mathrm{pp}$.

Laessle, Albert M.

1942 The plant communties of the Welaks area. Un1v. Flor1da Publ., B1al. Sc1. Ser. 4(1): 143 pp.

MoInhenny, Edward A.

1912 How I made a bird c1ty. Country l1fe in Amer108 22(9): 23-38.

Mackwarth-Praed, C. W., and Captain C. H. B. Grant

1957 B1rds of eastern and north eastern Afr1ce. Ser. I, I. Afrtean handboak of b1rds. Longmans, areen and Co., London, New York, Toronto. 806 pp.

Meanley, Brooke

1955 A nesting study of the I1ttle Blue Beron in eastern Arkansas. Willo on Bull. 67(2): 84-99.

Meinertzhagen, $R$.

1949 Notes on Saudi Arabian b1rds. Io 18 91(3): 465-482.

Meyerrleake, Andrew J.

1960 Comparative breeding behavlor of four specles of Narth Amerlcan herons. Publ. Nuttall Ornithologloal Club No. 2, $158 \mathrm{pp}$.

Mounts, Charles E.

1949 Annual Report of the Sanctuarles Conmelttee, For1da Audubon Soolety, Winter Park, March 5, 1949. Na. Naturalist, $22(3)$ : 59-61.

Noble, G. K.

1942 Further analysis of the social behavlor of the Black-crowned N1ght Heron. Auk 59(2): 205-224.

Noble, a. K., and A. Schmldt

1938 The 8001 al behavlor of the Black-crowned N1ght Heron. Auk $55(1): 7-40$.

R1ce, Dale W.

1956 Dyram1es of range expansion of Cattle Egrets in Flor1da. Auk $73(2): 259-266$. 
Skead, C. J.

1956 The Cattle Egret in South Arroa. Audubon Mag. 58(5): 206-209, 221, 224-226.

Bprunt, Alexander, $J_{1}$, and E. Burnham Chamberlain

1949 South Caralina bird 11fe. Unir. South Carolina Press, Calumbla. $585 \mathrm{pp}$.

Taylor, Arthur E.

1954 soll survey of Alechus County. U.S. Dept. Agr. Ser. 1940, No. 10, $66 \mathrm{pp}$.

Tomer, John 8.

1955 Notes on a heron rookery in northeastern Oklahowa. W11son Burl. $67(2)$ : 134-135.

Veiverde, Jose A.

1955-56 Essal sur I'Algrette Carzette (Egretta g. garzetta) en France. Alauda 23(3): 145-171; 23(4): 254-279; $24(1): 1-36$

Verwey, Jan

1930 Dle Paarungsblologle des Mschrethers. Zool. Jahrb., Abt. Allgem. Zool. Physiol. T1ere 48(1): 1-120.

Weller, M1lton $W$.

1961 Breeding blalogy of the Least Blttern. W1lson Burl. $73(1): 11-35$.

Wharton, Charles $\mathrm{B}$.

1958 The eoalogy of the cottonmouths Agk1strodon plsc1vorus plsolvarus Lacepede of Sea Harse Key, Farlda. UnpubIlshed Ph.D. dissertation, Untversity of Flarlda, $217 \mathrm{pp}$.

Whistler, Huge

1949 Popular handbook of Indlan blrds. Gurney and Jackson, London, Edenburgh, $560 \mathrm{pp}$.

Witherby, H. F. et al.

1947 The handbook of Brit1sh B1rds. III. H. F. and $G$. W1therby Itd., London. $387 \mathrm{pp}$. 


\section{BIOGRAPHICAL SKETCH}

Donald Alison Jenni was born June 20, 1932, at Pueblo, Colorado. In June, 1949, he was graduated from Kins City Union H1gh School. In June, 1953, he received the degree of Bachelor of Science from Oregon State College. Ile recelved the degree of Master of science from Utah State University in June, 1956. From July, 1955, unt11 1957, he served in the United States Air Force in Utah. Upon his release from the air force he enrolled in the Graduate School of the University of Forida. He has worked as a graduite assistant in the Department of Biology and the Florida State Museum. He has recelved grants in support of his research from the Florida Audubon Society, National Wlidife Federation, and Florida Acadery of Sciences.

Donald Alison Jenni is married to the former Mary Anne Hovland of Ortley, South Dakota. They have one child. Mr. Jenni is a member of the American Ornithologists' Union, American Soclety of Mammalogists, Ecological Society of America, Florida Audubon Society, South Dakota Ornithologists' Union, Wilson Ornithological Society, Phi Sigma, Xi Sigma Pi, and an assoclate member of Sigma Xi. 
This dissertation was prepared under the direction of the chairman of the candidate's supervisory comittec and has been approved by all members of that comittee. It was submitted to the Dean of the College of Arts and Sclences and to the Graduate Council, and was approved as partial fulfillment of the requirements for the degree of Doctor of Philosophy.

June 5, 1961

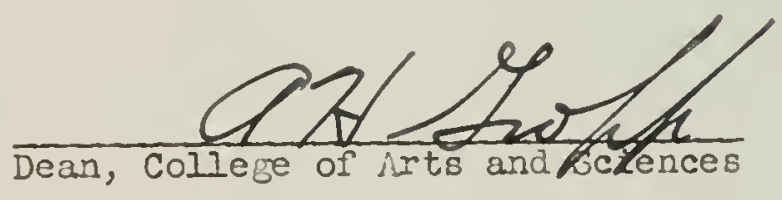

Dean, Graduate School

Supervisqry Comittee:

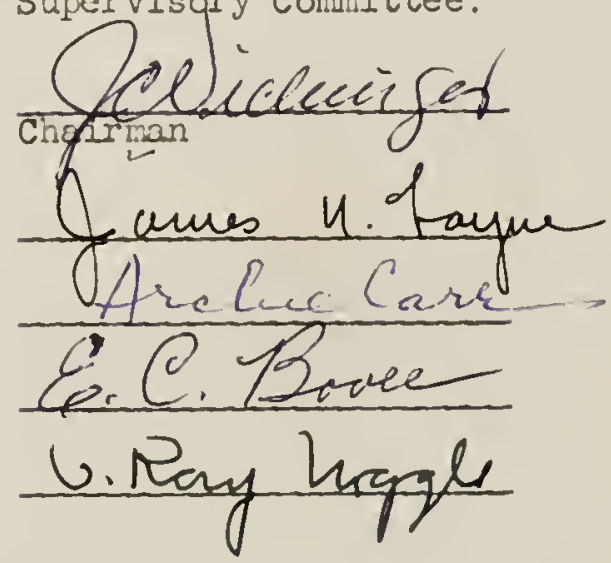


$91877^{\circ}$ 